\title{
PRODUÇÃO TERRITORIAL PORTUÁRIA NA AMAZÔNIA: AJUSTES, ORDENAMENTOS E PRÁTICAS ESPACIAIS FACE A PRODUÇ̃̃O DO COMPLEXO PORTUÁRIO DE SANTANA, AMAPPÁ, BRASIL
}

\section{Territorial port production in the Amazon: adjustments, ordinations and spatial practices face the production of the port complex of Santana, Amapá, Brazil}

\author{
Jondison Cardoso Rodrigues
}

Pós-Doutor pelo Programa de Pós-Graduação em Desenvolvimento Regional da UNIFAP jondisoncardosorodrigues@gmail.com

Jocianny Carla da Silva Sardinha Mestranda pelo Programa de Pós-Graduação em Geografia da UNIFAP jociannycarla@ hotmail.com

Magdiel Eliton Ayres do Couto Mestrando pelo Programa de Pós-Graduação em Geografia da UNIFAP magdiel.ayres@gmail.com

Jodson Cardoso de Almeida Mestre pelo Programa de Pós-Graduação em Desenvolvimento Regional da UNIFAP jodson.almeida@ueap.edu.br

Ricardo Ângelo Pereira Lima Docente do Programa de Pós-Graduação em Geografia da UNIFAP ricardoangelo_pereira@yahoo.es Artigo enviado para publicação em 15/08/2020 e aceito em 16/12/2020

DOI: $10.12957 /$ tamoios.2020.49034

\begin{abstract}
Resumo
A década de 2000 foi marcada por um acelerado processo de financeirização da economia mundial como também por uma forte conexão, integração e cooperação de regiões, países, instituições multilaterais, multinacionais e fundos, que vierem compor: i) um jogo de inclusão de espaços; ii) uma "modernização e seletividade espacial" (especialização produtiva e especulativa); iii) uma divisão internacional e territorial do trabalho; e, iv) a tecnificação do território. Esse cenário reverbera-se na região Amazônica no desembarque ou em planejamentos de uma série de projetos de infraestrutura, ligados ao setor do agronegócio; no caso, para a construção de corredor logístico de escoamento e fluidez de commodities agrícolas. Dentre desse corredor (no caso específico, o Arco Norte) está o estado do Amapá, particularmente, o munícipio de Santana, como fonte de atenção e projetos (concretos e alguns já em operação) e de centro de concentração do excedente e da acumulação capitalista, por meio de investimentos públicos e privados, principalmente no setor de infraestrutura portuária. Levando em consideração tais fatos o artigo tem por objetivo analisar a produção territorial portuária na Amazônia (política territorial), por meio dos ajustes, ordenamentos e práticas espaciais, na configuração espacial do Complexo Portuário de Santana, no estado do Amapá.
\end{abstract}

Palavras-chave: Política territorial; Logística; Amazônia.

\begin{abstract}
The decade of the 2000s was characterized by an accelerated process of financing of the world economy as well as a strong connection, integration and cooperation of regions, countries, multilateral, multinational institutions and funds, which came as part of: i) a game of space selection; ii) a "modernization and spatial selectivity" (productive and speculative specialization); iii) an international and territorial division of labor; and, iv) a technification of the territory. This scenario reverberates in the Amazon region on the landing or planning of a series of infrastructure projects, linked to the agribusiness sector; in this case, to build a logistical corridor for the flow of agricultural commodities. Among this corridor (in the specific case, Arco Norte) is the State of Amapá, especially the County of Santana, as a source of attention and projects (finished and some already in operation) and the center of concentration of surpluses and the capitalist accumulation, through public and private investments, mainly in the port infrastructure sector. Taking these facts into account, the article aims to analyze the territorial production in the Amazon (territorial policy), through adjustments, ordinations and spatial practices, in the spatial configuration of the Port Complex of Santana, in the State of Amapá.
\end{abstract}

Keywords: Territorial policy; Logistics; Amazon. 


\section{Introdução}

A década de 2000 foi marcada por um acelerado processo de financeirização da economia mundial, com forte conexão, integração e cooperação de regiões, países, instituições multilaterais, multinacionais e fundos. Agentes políticos e econômicos esses que foram responsáveis por promoveram um processo de "modernização e seletividade espacial" (especialização produtiva e especulativa), de divisão internacional e territorial do trabalho e de tecnificação dos territórios.

Essa conjuntura se inseriu a um contexto de constituição concreta de uma escalaridade produzida, que reage ou emerge de sobreposições de novas dinâmicas nas escalas regionais, nacionais e globais. Para Harvey (1998) e Massey (2015), a global(ização), por intermédio das localizações de poderes e ordens, possui bases concretas alicerçadas em bancos, fundos, multinacionais, organismos multilaterais e países hegemônicos. Com isso, há determinações sistêmicas e "ordens" globais que reverberam em diversas regiões, com lógicas e narrativas perpetradas por grandes agentes econômicos, como forma induzir ou obrigar mudanças: estruturais, organizacionais, regulatórias e/ou nos processos de arranjos institucionais políticos e econômicos. Com objetivo de reduzir os custos (e aumentar os lucros) de extração, transporte, transformação, exportação e expansão e acumulação de capital.

O Brasil interliga-se com a essas lógicas, ordens e determinações, principalmente a partir de 2007, via aumento de exportações de commodities, ocasionado por uma conjuntura: i) de fortes investimentos diretos estrangeiros; ii) em uma política de elevação de taxas de juros e câmbio; iii) de incentivos fiscais a empreendimentos estrangeiros; iv) de um Estado neodesenvolvimentista; e, v) de trocas comerciais com seu maior parceiro comercial atualmente, a China (RODRIGUES, 2018a).

Essa inserção no processo/circuito monopolístico financeiro internacional de acumulação-ampliação do capital, com aumento e foco na exportação de commodities, fez-se por meio de políticas territoriais e dos projetos de infraestrutura, cujo Programa de Aceleração do Crescimento (PAC) é emblemático (RODRIGUES, 2018a; 2018b; MARGARIT, 2019; MARGARIT; MIRANDA; BARREIRA, 2019).

Tal cenário de financeirização da economia, como também a entrada nesse processo e na construção de estratégias de políticas territoriais reverbera-se na região Amazônica $^{2}$, não apenas a partir de uma urbanização extensiva ${ }^{3}$ - e de suas implicações sobre a construção e redefinição da modernidade (MONTE-MÓR, 2015) - mas, sobretudo, pelo desembarque de uma série de projetos de infraestrutura alicerçados na tríade: imperialista, colonial (modernidade) e espoliadora. Projetos ligados, sobretudo, ao setor do agronegócio; no caso, para a construção de um projeto político e um corredor logístico de escoamento e fluidez de commodities.

Dentro desse (projeto político e) corredor (no caso específico, o Arco Norte) está o estado do Amapá, e em particular o munícipio de Santana, como fonte de atenção e de projetos (concretos e alguns já em operação) de investimentos públicos e privados, principalmente no setor de infraestrutura portuária. Considerando tais fatos, este artigo tem por objetivo analisar a produção territorial portuária na Amazônia (política territorial), por meio de ajustes, ordenamentos e práticas espaciais, na configuração espacial do Complexo Portuário de Santana, no estado do Amapá.

A pesquisa teve como recorte temporal dezembro de 2018 a janeiro de 2020. Pautou-se em: 1) levantamento bibliográfico sobre referenciais teóricos sobre complexos portuários no Brasil e na Amazônia; 2) legislações municipais (leis ordinárias e leis complementares); 3) ações políticas municipais, estaduais e federais no que tange a políticas territoriais concretizadas e sendo forjadas (como por exemplo, arrendamentos 
de áreas e concessões, enquanto formas de viabilizar a expansão portuária); 4) documentos oficiais, do Governo Estadual e Federal (Guia do Investidor - Amapá; Plano Mestre do Complexo Portuário de Santana, Arco norte: o desafio logístico e a Nota Técnica do Ministério de Infraestrutura acerca da modelagem do Programa de Arrendamentos Portuários do Governo Federal e a Licitação da área MCP02 no Porto Organizado de Santana/AP); 5) observações e registros fotográficos (dos portos e dos bairros).

A abordagem teórico-metodológica desta pesquisa pauta-se na análise crítica acerca das ações, relações e contradições inerentes ao movimento de transformações territoriais, lógicas territoriais e capitalistas e de produção e reprodução capitalista. Este caminho teórico-metodológico possibilita analisar os processos econômicos, as representações e ideologias, de maneira crítica (CLAVAL, 2013), relacionando a acumulação do capital e ações políticas com a produção das estruturas espaciais e sua relação interescalar de compreensão de tais processos (HARVEY, 2004, 2005a). Tornando-se, assim, componente necessário para entender a reprodução do espaço e do desenvolvimento geográfico desigual face a produção territorial de complexos portuários e, sobretudo, com relação aos "portos do agronegócio" (RODRIGUES; RODRIGUES, 2015; RODRIGUES; RODRIGUES; LIMA, 2019).

O artigo está dividido em cinco seções. A primeira seção é marcada por essa sucinta introdução ao debate. A segunda seção traz uma discussão sobre as políticas territoriais e as configurações dos complexos portuários da/na Amazônia. Já a terceira analisa a influência de ajustes e práticas espaciais na configuração da região amazônica como projeto político e corredor logístico, com foco no estado do Amapá, e, mais precisamente no município de Santana. A quarta apresenta um breve debate sobre o processo de produção territorial e ação do capital, por meio do Complexo Portuário de Santana/Amapá. E a quinta seção é remetida a algumas considerações reflexivas e críticas sobre o debate apresentado.

\section{Políticas territoriais e a produção de complexos portuários da Amazônia}

A formação socioterritorial da Amazônia é marcada por uma trajetória de exploração, perdas, danos, conflitos/conflitualidades e espoliação. É uma característica histórica comum no espaço-tempo, isto é, em "eventos" e produções de espaços que se expressam de forma mais recente (que reeditam projetos históricos sobre a região) com projetos e planejamentos de construção de hidrelétricas, ferrovias, hidrovias, rodovias e portos (RODRIGUES; LIMA, 2020).

Outra característica histórica comum é que o Estado esteve organicamente apoiando, mediando, legitimando, planejando, zoneando e financiando grandes projetos de infraestrutura na Amazônia, por exemplo: i) rodovias: $\mathrm{Br}$ - 010 (Belém-Brasília), Br-230 (Transamazônica), Br-163 (Cuiabá- Santarém), Br-364 (Cuiabá-Porto Velho), Br-319 (Porto Velho-Manaus); ii) Ferrovia: Ferrovia Carajás-Itaqui; iii) hidrelétricas: Coaracy-Nunes (1975), Curuá-Una (1977), Tucuruí (1984), Balbina (1987), Manso (1987), Samuel (1988), Lajeado (1999), Peixe Angelical (2006), São Salvador (2008), Dardonelos (2011), Rondon II (2011), Estreito (2012), Santo Antônio (2011), Jirau (2013), Santo Antônio (2014), Ferreira Gomes (2014), Santo Antônio do Jari (2014), Cachoeira Caldeirão (2016), Teles Pires (2014), Belo Monte (2015), São Manoel (2017) e Sinop (2019) (FEARNSIDE, 2019); iv) Portos: de Santarém, Vila do Conde, de Porto Velho e de Santana.

Portanto, o Estado esteve e continua ligado a tais processos, como um organizador político e territorial (RODRIGUES, 2018b); contribuindo e direcionando planejamentos e 
políticas que se aliançam com lógicas capitalistas (HARVEY, 2005a). No caso, o papel do Estado dialogando com Harvey (2005b), seria contribuir para as reorientações espaciais, por meio de sistemas regulatórios, de abertura de novos mercados, novas capacidades produtivas/especulativas e novas possibilidades de recursos e mão-de-obra. Consequentemente contribuindo

[Na] produção do espaço, [n]a organização de novas divisões territoriais de trabalho, [n]a abertura de novos e mais baratos complexos de recursos, de novos espaços dinâmicos de acumulação de capital, e a penetração em formações sociais pré-existentes pelas relações sociais capitalistas e acordos institucionais (tais como regras contratuais e acordos de propriedade privada) são formas de absorver excedentes de capital e mão-de-obra (HARVEY, 2005b, p.12)

Portanto, o Estado se pautou e vem se pautando em políticas territoriais que segundo Sánchez (1991, p. 72) seria um conjunto de medidas estratégicas, a médio e longo prazo, assim como pelas correspondentes formulações de atuação dirigidas a intervir sobre o território, a fim de que assuma as formas adequadas ao conjunto dos interesses que pressionam e compõem o jogo e poder político.

Ainda com relação à política territorial Rückert (2007) aduz:

\begin{abstract}
Entende-se também que as políticas territoriais extrapolam a noção dos planos regionais de desenvolvimento. Elas abrangem toda e qualquer atividade que implique, simultaneamente, uma dada concepção do espaço nacional; uma estratégia de intervenção ao nível da estrutura territorial bem como mecanismos concretos que sejam capazes de viabilizar estas políticas (RÜCKERT, 2007, s. p.).
\end{abstract}

Para Costa (2012) as políticas territoriais, como processo consciente de manipulação do território, vêm reduzindo territórios em território, isto é, uma estrutura material, homogênea e sem um conjunto múltiplo de territorialidades, espacialidades e temporalidades e diversos segmentos sociais que usam e possuem "interesses" diversos sobre os territórios (HAERSBAERT, 2006; 2020). Dessa maneira, a política territorial como ação territorial do Estado, passam a ser políticas do qual o território reduz-se a "territórios de projetos" (portanto, não de vida e de reprodução social), particularmente para grupos hegemônicos, que se apropriam "reticularmente do espaço, ou seja, privilegiando pontos e linhas e não o 'espaço de todos' no seu conjunto" (HAERSBAERT, 2006) e para uso corporativo (privado) e com privatização dos territórios.

A Amazônia é marcada historicamente por "territórios de projetos", isto é, por planos, políticas territoriais e ações seletivas, em benefício de grupos econômicos hegemônicos. Sendo, portanto, objeto utilitário sempre pautado na (construção permanente) narrativa de um território como vocação natural e fonte de recursos naturais.

Tal narrativa calcada no imaginário (da década de 1970, principalmente) de vazio demográfico e precariedade em termos de desenvolvimento, e, também:

a) a Amazônia seria um macrossistema homogêneo de floresta, rios e igarapés em toda a sua extensão, com uma natureza amazônica superabundante, autorrecuperável e inesgotável; b) Índios e caboclos viveriam em terras excessivamente vastas e pouco produtivas; c) estigmatização e inferiorização do extrativismo vegetal, da pesca, caça e da pequena produção agroextrativista, como algo primitivo e antieconômico; e, d) colonialidade/colonialismo nos planos e projetos estatais - o Estado têm entendido que somente o grande capital teria o impulso capaz de desenvolver a região (RODRIGUES; LIMA, 2020, p. 96). 
Assim, as políticas territoriais foram forjadas no discurso estatal (alimentado e/ou construído pelo setor empresarial) para defender, desenvolver e proteger as fronteiras da região e as poucas populações existentes. Além disso, tais políticas dispersadas com o discurso de fonte de diminuição de: desigualdades (sub)regionais e socioespaciais e o correspondente grau de exclusão socioeconômica da população. Tendo seu arauto mais recente ("mensageiro do caminho das bonanças e apagamento das desigualdades") o setor do agronegócio, e sua política de exportação de commodities (RODRIGUES; LIMA, 2020). Algo dispersado, sobretudo, no discurso estatal, particularmente nos estados do Amapá e Pará (RODRIGUES; LIMA, 2020).

Para Carmo, Barreira e Miranda (2020), as políticas de desenvolvimento no Amapá, proporcionado pelas grandes obras de infraestrutura, vem introduzindo uma nova lógica de organização territorial, ligados aos interesses do mercado, capitais, exportação e agronegócio e perpetuando estratégias que visam a manutenção do poder e da concentração da renda das elites e arranjos político-econômicos hegemônicos. E isso vem se fazendo, por um

[...] aparato político mobilizado para influenciar decisões e convencer a opinião pública da necessidade de continuidade de tais empreendimentos. Baseado no discurso de que as grandes obras de infraestrutura no Amapá são indispensáveis para o desenvolvimento do País, o Estado forja uma ideia equivocada da imperiosa necessidade na execução destas obras, qualificando os empreendimentos e reduzindo as críticas a partir de um discurso que exalta a necessidade de bem estar coletivo, mesmo que para isso seja necessário desestruturar comunidades e degradar o meio ambiente. Para tanto, é difundida a falácia de que os impactos socioambientais decorrentes dos grandes projetos de desenvolvimento no Amapá são infinitamente menores do que seus benefícios (CARMO; BARREIRA; MIRANDA, 2020, p. 255).

Segundo Costa (2012), é necessário compreender as políticas territoriais de forma sistêmica e processual, desde a formulação para entender como e quais os atores políticos participam da sua construção e quais os interesses e lobbies ${ }^{5}$. Isso porque no Brasil, as políticas territoriais são marcadas ou permeadas por ajustes espaciais e práticas espaciais ${ }^{6}$ com baixa ou nenhuma participação social, dos diversos e múltiplos atores sociais e políticos.

As políticas territoriais, particularmente voltadas para o setor portuário expressam-se no planejamento e execução das estratégias estatais e empresariais que impactam os territórios e reorganizam o espaço. Logo, os ajustes espaciais são visualizados por meio de financiamentos públicos, incentivos hídricos e fiscais, investimentos nas infraestruturas portuárias (públicas e privadas) e na constituição de leis e decretos que possibilitem segurança jurídica ao setor empresarial. Já as práticas espaciais podem ser observadas nas concessões de terras e autorizações para construção de portos privados em diversas regiões do país (RODRIGUES; RODRIGUES; LIMA, 2019). Tudo isso gerou um ganho de escala, que constitui, em síntese, o aumento de lucros privados.

Na visão de Rodrigues (2018b), a lógica de produção de complexos portuário, por meio de políticas territoriais, vem sendo usadas como um discurso de forma a reduzir o tempo de armazenamento de mercadorias, promover a maior fluidez e o aumento da integração entre os elementos do sistema complexo de produção mundial, de relações e redes informacionais/relacionais e financeiras.

Como destacam Huertas (2010) e Martner-Peyrelongue (2014): 


\begin{abstract}
Os caminhos, as pontes, os portos, a pavimentação de uma via são elementos cuja capacidade reside exatamente em condicionar (ou ao menos estabelecer) as variáveis intrínsecas à fluidez territorial - intensidade, qualidade e natureza dos fluxos - que expressam o poder de definir e limitar a dinâmica dos agentes sociais (HUERTAS, 2010, p. 147).

Na medida em que pode ser movido indistintamente por um caminhão, uma ferrovia ou um navio, ele evita as rupturas de carga nos terminais portuários ou interiores. Tais características tecnológicas permitem acelerar os fluxos de mercadorias e integrar efetivamente processos produtivos fragmentados no espaço. Nessa medida, permite articular os portos com regiões distantes do interior (MARTNER-PEYRELONGUE, 2014, p. 106).
\end{abstract}

O ajuste espacial (que está nas sublinhas dos autores anteriores), manifesta-se enquanto possibilidade para a expansão e reestruturação geográfica do capital(ismo), como afirma Harvey (2001):

(a) o capitalismo não poderia sobreviver sem estar geograficamente expansionista (e perpetuamente buscando "soluções espaciais" para seus problemas), (b) que as principais inovações em tecnologias de transporte e comunicação eram condições necessárias para que a expansão ocorra (daí a ênfase na evolução do capitalismo em tecnologias que facilitaram a velocidade para cima e a diminuição progressiva das barreiras espaciais à circulação de mercadorias, pessoas, informações e ideias sobre o espaço) e (c) os seus modos de expansão geográfica dependia fundamentalmente do facto era a busca de mercados, competências laborais frescas, recursos (matériasprimas) ou novas oportunidades para investir em novas unidades de produção, que era principalmente em jogo (HARVEY, 2001, p.25-6).

A perspectiva de Harvey (2001) acerca dos ajustes espaciais e práticas espaciais (como destacada anteriormente) se entrelaça com que vem se chamado de "sistema agroalimentar", o agronegócio como todo (PAULA; SANTOS; PEREIRA, 2015) e suas estratégias para regular os mercados e reduzir flutuações excessivas de preços das commodities agrícolas:

[O] sistema de formação de preços se tornou extremamente complexo, refletindo a relação entre oferta e demanda, influenciadas por condições de transporte, armazenagem e financiamento, por políticas de abastecimento e comercialização etc.(VALIANTE, 2013), e pela atuação de grandes empresas comerciais e agroindustriais, agências nacionais de comércio, cooperativas de produtores etc.) (PAULA; SANTOS; PEREIRA, 2015, p, 298) ${ }^{7}$.

Tomando esse "pensamento lógica" econômica e política de ajustes e práticas espaciais e racionalidade desse sistema, é conformada a partir de 2007, quando houve uma ampliação na visão estratégica do Estado brasileiro, com investimentos "pesados" no setor de transporte, logística de cargas e informações e armazenagens (RODRIGUES; RODRIGUES; CASTRO, 2014). Os portos passam a ser enxergados (por compor esse setor) como "o termômetro que mede a temperatura da economia de um país" (GILBERTONI, 2000). Assim, duas grandes políticas merecem destaque: o Programa de Aceleração do Crescimento (PAC) e a Nova Lei dos Portos (Lei n 12.815/2013). As duas políticas objetivavam estruturar e organizar um arranjo institucional, jurídico e logístico, e assim criar uma agenda (geo)política e (macro)econômica de exportação de commodities e na construção de um corredor logístico de fluidez de commodities.

No que diz respeito ao PAC este se apresentou em duas fases. A primeira denominada de PAC I (2007-2010), do qual o governo federal visava estimular o crescimento da economia brasileira, para isso promoveu investimento no setor de 
infraestrutura: portos, rodovias, aeroportos, redes de esgoto, geração de energia, hidrovias, ferrovias. Já o PAC II, apesar de possuir os mesmos objetivos do PAC I, amplia-se face a disponibilidade de novos recursos e aumento da parceria com estados e municípios (RODRIGUES; RODRIGUES; CASTRO, 2014).

Segundo Gobbi, Carraro e Furlan (2015, s.p.):

O PAC até 2014 investiu R \$ 5,27 bilhões em obras de dragagem, infraestrutura portuária e serviço de inteligência logística, em 24 portos. Somente o PAC, entre 2007 e 2014, injetou, na área de infraestrutura, particularmente de infraestrutura portuária e de transporte, rodoviário, ferroviário, hidroviário e aeroviário, 132,3 bilhões de reais; 65,4 bilhões de reais investidos, de 2007 a 2010, e R\$ 66,9 bilhões de reais, de 2011 a 2014.

Quanto a Lei $\mathrm{n}^{\circ}$ 12.815/2013 (Nova Lei dos Portos), esta promoveu alterações no sistema portuário brasileiro, onde um dos seus principais objetivos foi criar um cenário propício para promover maior agilidade e modernização do setor portuário, pautado nas alterações no modelo das concessões e arrendamentos de áreas e foco na construção de portos privados e participação de capital estrangeiro. No caso de participação privada, a partir Lei $n^{\circ} 12.815 / 2013$, houve avanços, já que os ordenamentos jurídicos anteriores só permitiam a movimentação de mercadorias pelos portos privados de cargas de propriedade dos proprietários dos portos e agora passam a exportar cargas de terceiros (RODRIGUES, 2018a; RODRIGUES, 2018b).

Essas políticas territoriais, que reverberam na Amazônia, criam um cenário propício para a ampliação do neoextrativismo e do colonialismo (colonialidade) sobre a região. Diante do contexto mundial de exportação de commodities, o capital se manifesta e ganha movimento no espaço, não apenas como área ativada pelo neoextrativismo, mas como um grande corredor logístico de escoamento de riquezas (água, solo, minérios, floresta, energia, trabalho), propagando-se sobre a região Amazônica, por meio de redes ou circuitos espaciais de produção.

\section{Ajustes e práticas espaciais na configuração da Amazônia como corredor logístico}

Os complexos portuários surgem como grandes ajustes espaciais, permeados de práticas espaciais, uma vez que tais complexos constituem um "ponto nó" entre: os sistemas aquaviários e terrestres, de pessoas e mercadorias, informações, relações e comunicações, concentrações de poder e técnica e sistemas de objetos e sistemas de ações. Desta forma são considerados elos de cadeias logísticas, pois segundo Gilbertoni (2000, s. p.), "o que precisamos analisar quando se fala em porto, então, é a cadeia logística dos meios de transporte, onde o porto aparece como elo fundamental nas trocas comerciais, seja no âmbito interno seja no âmbito internacional".

Desse modo, os "pontos nós" constituem uma construção social de unidade técnica no espaço, simbolizando no plano concreto da territorialidade, um significativo poder/força capaz de unificar e globalizar e conformar um espaço concreto homogêneo, cuja saberes e práticas espaciais visualizados na escala local, nacional e internacional seriam expressão da modernidade e da sociedade recente (MOREIRA, 2017), supostamente avançada, civilizada, desenvolvida e de grande futuro.

Tal compreensão de sociedade ou projeto de sociedade vem sendo usados pelo(s) poder(es) público(s) e por agentes privados, com a produção de complexos portuários, no Arco Norte (RODRIGUES; LIMA, 2020). Foco que se materializa e territorializa-se, por meio de processos de ajustes e práticas espaciais, de modernização e arrendamento de 
áreas, por exemplo, de Barcarena (Pará), São Luís (Maranhão), Porto Velho (Rondônia) e Santana (Amapá).

Verifica-se de forma objetiva uma demarcação de um processo de "interação seletiva" (MOREIRA, 2017): i) de tecnificação do território, ou, mais precisamente, a tecnificação localizada; ii) a demarcação simbólica e política do terreno concreto de poder e os jogadores que irão jogar e lucrar; e, iii) o controle, privado e privatizado, do espaço. Mas também se notabiliza como uma forma de replicação ou reprodução de uma racionalidade técnica que marca o planejamento estatal calcada em uma perspectiva autoritária e antidemocrática (e violadora de direitos humanos, não-humanos, territoriais e étnicos), cujas "regiões e lugares [são] postos à margem desse processo de rearticulação atual acelerada do território nacional" (COSTA, 2016. p. 4).

Ajustes espaciais permeados de práticas espaciais, dos quais são visualizados (no município de Santana) com a promoção:

i) De zoneamento (alterando zonas urbanas/Lei 1021/2013);

ii) Concessões terras;

iii) Reservas de territórios;

iv) A lei sobre uso, ocupação e parcelamento do solo macrourbano (Lei 949/2012 ${ }^{8}$;

v) A função social da propriedade urbana (Lei 1024/2013);

vi) Instituição de um novo código tributário, para receber tributos de empresas (Lei Complementar 014/2017);

vii) Instituição de códigos de obras e instalações (Lei 943/2012);

viii) Reorganização de estrutura administrativa (Lei Complementar 007/2015); e,

ix) Lei transformando a companhia Docas de Santana de Empresa Pública a Sociedade de Economia Mista (Lei 1097/2016).

Todo esse ordenamento converge com que ocorrera no município de Itaituba face a chegada de grandes agentes econômicos ligados ao setor portuário/agronegócio, vide Rodrigues e Rodrigues (2016), e, principalmente Rodrigues (2018a).

Tal quadro significaria dialogando com Haesbaert (2006, p. 120): "territorializarse é, sobretudo, exercer controle sobre os movimentos - de pessoas, objetos ou informações - que se dão no e pelo espaço (Sack, 1986) e, a partir daí, dominar e apropriar-se deste espaço, podemos dizer que formar territórios é, automaticamente, 'ordená-los"'. Ou como destaca Harvey:

[O] inacreditável poder de movimentar moeda ao redor do mundo, tão característico da era contemporânea, exige não apenas sistemas de telecomunicações bem organizados, mas, no mínimo amparo seguro de sistema de crédito pelas instituições públicas, financeiras e jurídicas [...] Provavelmente, a capacidade de mover mercadorias depende da construção de um sistema de transporte sofisticado, eficiente e estável, amparado por todo um conjunto de infra-estruturas sociais e físicas (de serviços jurídicos a armazéns), facilitando e assegurando a troca (HARVEY, 2005a, p.148).

Assim, o conceito de logística (com inserção de portos nos territórios) segundo Silveira (2011, p.30) principalmente a partir da década de 1980, ganha relativa importância por estar ligado ao desenvolvimento das estratégias das empresas globais para alcançarem novos mercados, ou seja, a lógica passou a atender as demandas corporativas e favorecer a aceleração dos fluxos econômicos contemporâneos. Isso pode ser observado, parcialmente, no discurso (neo)desenvolvimentista do Estado:

Ao longo do exercício de 2012, intensificaram-se as discussões sobre a alteração do Marco Regulatório então em vigor, a Lei $n^{\circ} 8.630 / 93$. O diagnóstico, à época, era o de que havia a necessidade de dar maior ênfase na execução de investimentos privados nos portos, com vistas ao aumento da 
capacidade de movimentação dos portos e terminais brasileiros, seja por implantação de novas instalações, seja pela melhoria da infraestrutura das instalações com contratos vigentes, resultando com isso no aumento da competição do setor, em melhoria da eficiência na prestação dos serviços portuários, consequentemente, a redução do chamado "Custo Brasil" (BRASIL, 2019, p. 1).

Existe um enorme interesse público para que os portos operem com eficiência e segurança e que os serviços sejam prestados de forma competente e ajudem no desenvolvimento econômico regional e nacional, considerando seu papel vital no comércio internacional (BRASIL, 2019, p. 7).

Sabe-se que um dos principais mecanismos para reduzir os preços e aumentar eficiência é através do estímulo ao aumento da concorrência. Sempre que há demanda e áreas de expansão disponíveis, recomenda-se a licitação de novas estruturas, o aumento da capacidade das áreas existentes (ganhos de produtividade) e melhorias estruturais que ampliem o dinamismo do porto (BRASIL, 2019, p. 7).

\section{Brasil (2016) e Brasil (2017) enfatizam que:}

Há espaço para crescimento de produtividade no Brasil, que tem estado a níveis muito inferiores aos verificados nos países desenvolvidos. Uma das formas mais rápidas de promover ganhos de produtividade é por meio do investimento em infraestrutura, tendo em vista o grande poder de irradiação dos investimentos em infraestrutura, notadamente de transportes e energia, para os outros setores da economia, a redução de custos de produção e transação, a aproximação de mercados e criação de oportunidades de negócio e o aumento de estoque de capital fixo (BRASIL, 2016, p. 64).

A rápida expansão do comércio mundial, com o surgimento de novos players no cenário internacional, como China e Índia - que representam desafios logísticos importantes, dada a distância desses mercados e sua grande escala de operação - exige que o sistema de transporte brasileiro, especialmente o portuário, seja eficiente e competitivo. O planejamento portuário, em nível micro (mas articulado com uma política nacional para o setor), pode contribuir decisivamente para a construção de um setor portuário capaz de oferecer serviços que atendam à expansão da demanda com custos competitivos e bons níveis de qualidade (BRASIL, 2017, p. 9).

\section{Ainda para Brasil (2016):}

Os dirigentes políticos são obrigados a considerar uma ampla variedade de pontos de vista e pressões, e apenas dois deles são o desejo de conceber políticas que maximizem a eficiência econômica e distribuam recursos de maneira socialmente preferível. Por isso, sistemas de planejamento robustos são primordiais para garantir eficiência alocativa e mitigar o risco de falhas de governo (p. 66).

[Com isso o] Aumento da eficiência produtiva em áreas consolidadas: trata-se aqui de projetos voltados a incrementar a eficiência o abastecimento de insumos e do escoamento da produção em áreas que ostentam maior grau de consolidação e de desenvolvimento em sua estrutura produtiva. Os projetos incluídos nessa categoria são, na sua maioria, de aumento de capacidade de infraestrutura viária (duplicações e faixas adicionais), dragagem e vias de acesso portuário, eliminação de conflitos entre ferrovias e zonas urbanas (contornos, passagens de nível) (p. 73).

O interesse público, do Estado, está na inserção no processo mundialização de trocas, como destacado nas citações anteriores, sobretudo: na busca do aumento da movimentação de mercadorias e serviços e melhorias estruturais que ampliem o dinamismo dos portos. $\mathrm{O}$ aumento de dinamismo é verificado e interligado aos vários 
projetos de infraestrutura portuária na Amazônia que já são uma das maiores fontes materializadas de investimentos, como também de futuros investimentos (público e privado) (RODRIGUES; RODRIGUES; LIMA, 2019; RODRIGUES; LIMA, 2020).

Uma das principais estratégias do Estado, na segunda década do século XXI, é a criação do projeto Arco Norte ((RODRIGUES, 2018a), que de acordo com Brasil (2016): "O Arco Norte compreende eixos de transporte que levam a portos situados acima do paralelo $16^{\circ} \mathrm{S}$ " (p. 9).

[...] [A] logística voltada para o Arco Norte, aqui delimitado como o sistema de transportes, em seus vários modos, responsável pelo escoamento de cargas e insumos com a utilização dos portos ao norte do Brasil, desde Porto Velho, em Rondônia, passando pelos Estados do Amazonas, Amapá e Pará, até o sistema portuário de São Luís, no Maranhão (BRASIL, 2016, p. 15).

O projeto Arco Norte, por exemplo, propõe a instalação de mais 96 portos nos estados que fazem parte do projeto (Rondônia, Amazonas, Amapá, Pará e Maranhão) (RODRIGUES, 2018a; 2018b; RODRIGUES; LIMA, 2019). Sendo que muitos portos já estão em operação como: da Cargill (Itaituba e Santarém/Pará), Porto da ADM (Barcarena/Pará), Porto Flutuante do Transporte Bertolini/ADM (Itaituba/Pará), Unitapajós (Bunge-Amaggi/Itaituba e Barcarena/Pará), Hidrovias do Brasil (Barcarena e Itaituba/Pará), Cianport (Itaituba/Pará e Santana/Amapá), Caramuru Alimentos (Santana/Amapá e Itaituba/Pará), Porto de Itaqui/Maranhão, Terminal Graneleiro Hermasa (Itacoatiara/Amazonas), Porto de Porto Velho (Porto Velho/Rondônia), Porto Cargill Agrícola (Porto Velho/Rondônia), Estação Cojubinzinho (Porto Velho/Rondônia), Terminal de Expedição de Grãos Portuários (Porto Velho/Rondônia) e Porto F. H. de Oliveira Peixoto (Porto Velho/Rondônia).

Além desses portos há um processo de "construção" (pelo Estado e multinacionais/bancos/fundos) de projetos portuários, como: o Porto São Luís ${ }^{9}$ (São Luís/Maranhão), da LDC (Rurópolis/Pará), da RTL (Itaituba/Pará), da J.F. de Oliveira Navegação Ltda (Itaituba/Pará), do Terminal Portuário de Alcântara/GPM - Grão Pará Multimodal Ltda (São Luís/Maranhão) e Cianport (Santana/Amapá, na Ilha de Santana), Hidrovias do Brasil (Barcarena/Pará, ampliação do porto, que é outro porto), Cevital (em Barcarena/Pará), Cargill (na Ilha Xingu, localizado no município Abaetetuba/Pará e dentro do Projeto de Assentamento Agroextrativistas/PAE). Além do Grupo ATEM, que está processo de mudança de perfil de movimentação de mercadorias (junto a ANTAQ), no caso, de combustíveis para grãos.

Somente no Oeste do Pará (Itaituba e Rurópolis) há o planejamento de instalação de mais de 40 portos e no baixo Tocantins, no Pará (Barcarena e Abaetetuba), são planejados mais de 20 portos. Constituindo uma rede de relações técnicas, econômicas e políticas hegemônicas, com objetivo de conexão a um regime sincronizado de cadeia de valores especulativos e rentistas internacionais.

Verifica-se no projeto Arco Norte uma intencionalidade concreta, materializada, de modernização conservadora, de ampliação de soldagem territorial local, nacional e global, isto é, uma conexão aos circuitos produtivos e financeiros globais, principalmente com a China (para onde são direcionados a maioria das exportações). Trata-se de um programa político, de Estado (e com alianças a lógicas capitalistas), como também: i) um vetor logístico e ii) um corredor de transporte e movimentação de mercadorias. Programa político com total sinergia com o setor do agronegócio (RODRIGUES, 2018a; 2018b). Como também uma política de ampliação e soldagem territorial (local $\leftrightarrow$ nacional $\leftrightarrow$ global) e a conexão ao circuito produtivo-financeiro internacional, de bancos e fundos, bem como uma cadeia global de valor e de commodities (RODRIGUES, 2018b). 
Harvey (2005a) destaca que é inevitável e indispensável o aperfeiçoamento do transporte e da comunicação para diminuição de custos na cadeia de valor, assim como no surgimento de novos espaços para a acumulação do capital. Isso porque,

[...] a redução nos custos de realização e circulação ajuda a criar espaço novo para a acumulação de capital. Reciprocamente, acumulação do capital se destina a ser geograficamente expansível, e faz isso pela progressiva redução do custo de comunicação e transporte (HARVEY, 2005a, p. 50).

$\mathrm{Na}$ mesma perspectiva e convergindo com o Projeto Arco Norte, o projeto denominado de Corredores Logísticos Estratégicos: Complexo de Soja e Milho, que foi lançado dia 15 de maio de 2017, também se pauta no deslocamento dos principais produtos da economia brasileira, que são: complexo de soja e milho; petróleo e combustíveis; minério de ferro; açúcar; carne; e, automóvel via Corredor Norte (Figura 1). Projeto esse que se pauta o Programa de Parcerias de Investimentos (PPI), por meio de macroeixos estruturadores de ações, planejamento e políticas para exportações de commodities

Rodrigues (2018a) ressalta que o projeto Corredores Logísticos Estratégicos é o próprio Projeto Arco Norte, por se sustentar na fluidez, via Corredor Norte, a partir : a) da antecipação e organização espaço-temporal, já em curso; b) a construção de políticas de interesses de uma fração de uma classe hegemônica e com forte ligação com multinacionais, fundos de investimentos e novos países hegemônicos, no caso, a China; c) de ações futuras, para construir, consolidar e mobilizar ações.

Figura 1: Corredores Logísticos Estratégicos

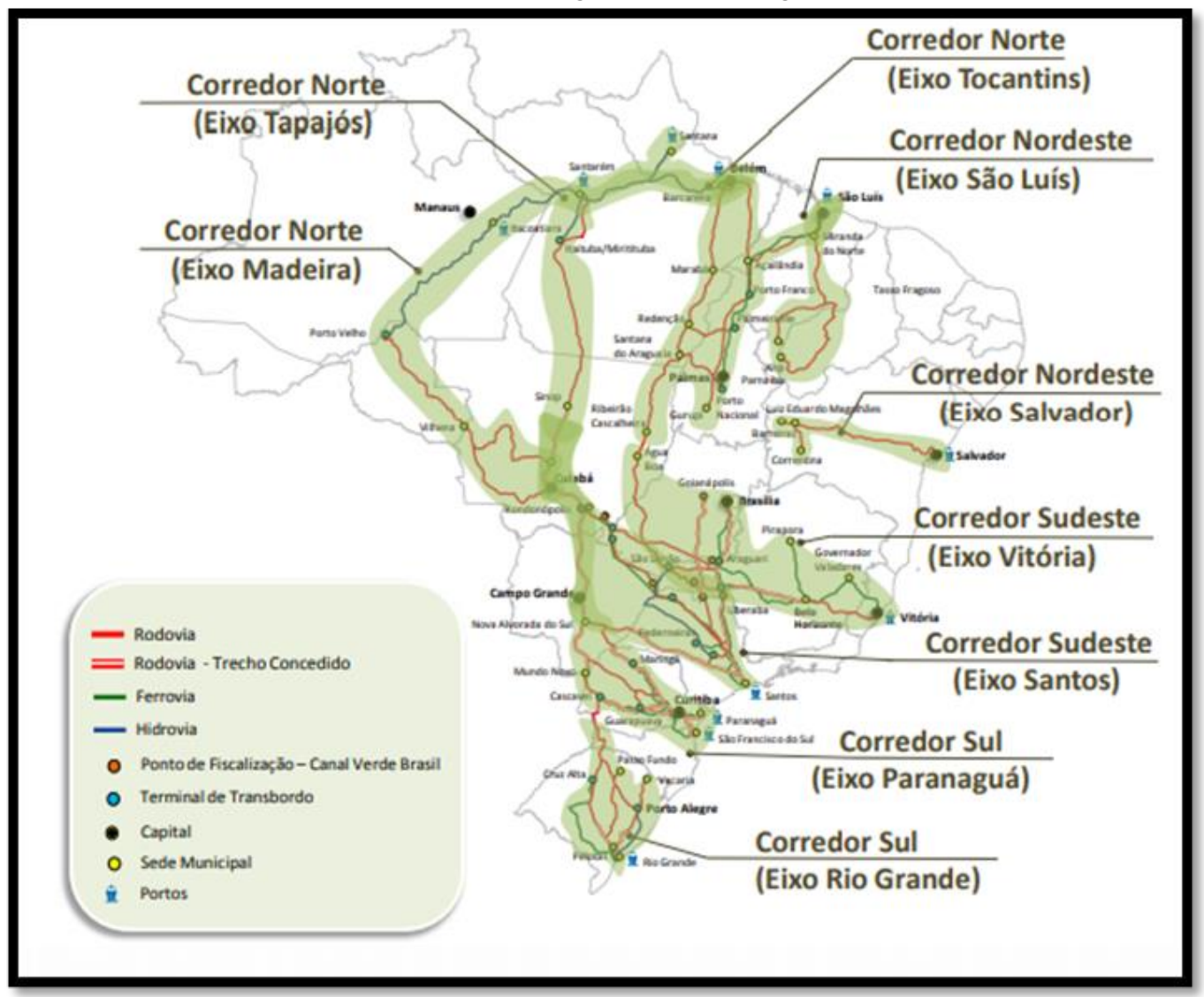

Fonte: MTPA (2017, p. 37) 
Nessa perspectiva, principalmente no que tange a redução de custos de comunicação, de transporte e consequentemente no acionamento de novos espaços, é que o Arco Norte e o Corredor Logístico ganham envergadura nesta rede logística e espoliativa, destacando-se na utilização do modal hidroviário e rodoviário. São grandes agentes do capital, que vem com ótimos olhos tal projeto, já que haverá a diminuição de tempo e transporte e circulação (escoamento de soja e milho) dos grandes produtores da região Centro-Oeste aos portos do Arco Norte. Consequentemente aumentaria ainda mais lucro do setor do agronegócio e construiria, no caso, intensificaria ainda mais uma economia de contradições e assimetrias que conformam (e são componentes extrativo e rentista) tal setor (SVAMPA, 2019) ${ }^{10}$.

As vantagens do Arco Norte enquanto um corredor seria a utilização da multimodalidade e principalmente a economia de escala, isto é, a distância diminuiria de $2.300 \mathrm{~km}$ utilizando o modal rodoviário até os portos de Santos e Paranaguá, para $1.100 \mathrm{~km}$ (em média) que são substituídos por $820 \mathrm{~km}$ de curso fluvial. Ademais, um comboio de doze barcaças consegue transportar 33.600 toneladas de grãos de uma única vez, o que substituiria 900 carretas pela via rodoviária e centenas de motoristas (trabalhadores) de caminhões. Por fim, o aumento na entrega de volumes de mercadorias, a diminuição no tempo de entrega, consequentemente, o aumento de lucros de grandes produtores rurais, tradings e multinacionais.

Amapá (2019) corrobora o trabalho de Chelala e Chelala (2019) ao destacar:

Em relação a logística, estudos recentes comprovam que na exportação da soja pelo porto de Santana até roterda, na Holanda, o frete custa cerca de US\$75/ton, enquanto partindo do Paraná via Porto de Paranaguá ofrete para mesmo trecho importa em US\$ 125/ton. Já em relação a Mato Grosso com a mesma logística do Paraná o custo do frete corresponde a US\$ 185/ton (AMAPÁ, 2019, p. 45).

A premissa discursiva de Brasil (2017), Brasil (2019a), e, principalmente de Amapá (2019), no Guia do Investidor - Amapá, há a apresentação do estado do Amapá, como uma espécie de menu territorial, isto é, um cardápio oferecido para a escolha do cliente:

O Amapá conta com 2,4 milhões de hectares de recursos florestais, 500.000 hectares de cerrados para a produção de grãos e ainda conta com muitos recursos naturais como manganês, ferro e granito, portanto, é necessário ampliar e modernizar ainda mais o porto, para permitir que possa tornar-se mais relevante ${ }^{11}$ (BRASIL, 2019a, p. 2).

O Guia do Investidor - Amapá (do Governo do Amapá) (AMAPÁ, 2019) apresenta também a questão de terras para produção de grãos (no caso, 400 mil hectares) e ainda destaca que as terras amapaenses são muito mais baratas ${ }^{12}$ do que outras regiões (Santarém e Redenção, no Pará; Alta Floresta e Sinop, no Mato Grosso; Ponta Grossa, Cascavel e Londrina, no Paraná, Boa Vista, em Roraima; e, Urucuí, no Piauí). Ainda para Amapá (2019) considerando esses 400 mil hectares potenciais para o agronegócio, a receita (de soja e milho, lucro privado) gerada seria de 2,032 bilhões de reais ${ }^{13}$.

Brasil (2017) converge com Amapá (2019) e Brasil (2019) ao destacar:

Outro fator impulsionador para a projeção de grãos no Complexo de Santana é a expansão da produção do Amapá. Até recentemente, um dos principais complicadores para a produção e exportação de grãos no estado era o fato de a União deter a posse de $95 \%$ das terras amapaenses. Em abril de 2016, no entanto, foram transferidos 4,5 milhões de hectares para o Governo do Amapá, possibilitando a regularização dos produtores e que estes consigam maiores financiamentos para investir na produção agrícola. Além disso, é esperado que 
a cultura de grãos no estado atinja 300 mil hectares de cerrado em um intervalo de 15 anos, tendo como carro (BRASIL, 2017, p. 146-7)

Segundo a Embrapa, esse montante de terras é considerado com total aptidão agrícola, podendo produzir até três safras seguidas devido às condições climáticas favoráveis de nove meses de chuvas regulares por ano (e apenas três de estiagem) (BRASIL, 2017, p.147).

Cabe destacar que esse novo vetor espacial e produtivo especulativo, os grãos (soja e milho), são transportados de diversos municípios do Mato Grosso, utilizando a Br163, com destino os portos de Miritituba (hoje estão operando seis portos: Cargill, Hidrovias do Brasil, Cianport, Unitapajós, Transportes Bertolini/ADM e Caramuru Alimentos), que se localizam no município de Itaituba - Pará. Chegando aos portos, as commodities são colocadas em barcaças e pelo rio Tapajós destina-se ao porto de Vila do Conde, em Barcarena, Santarém e Santana (com escoamento ainda muito modesto, do porto da Cianport e o porto da Caramuru Alimentos, em Santana, mas com planejamento de grande fluxo). O porto da Cianport e o porto da Caramuru Alimentos (em Santana), também são armazenadoras, distribuidoras e transbordadora de grãos, do sistema logístico modal e agroalimentar no território Amapaense, da produção de grãos (Figura 2). Portanto, o território amapaense torna-se uma célula do regime/sistema rentista e financeirizada, isto é, um território transnacionalizado.

Figura 2: Sistema logístico modal e agroalimentar no território Amapaense

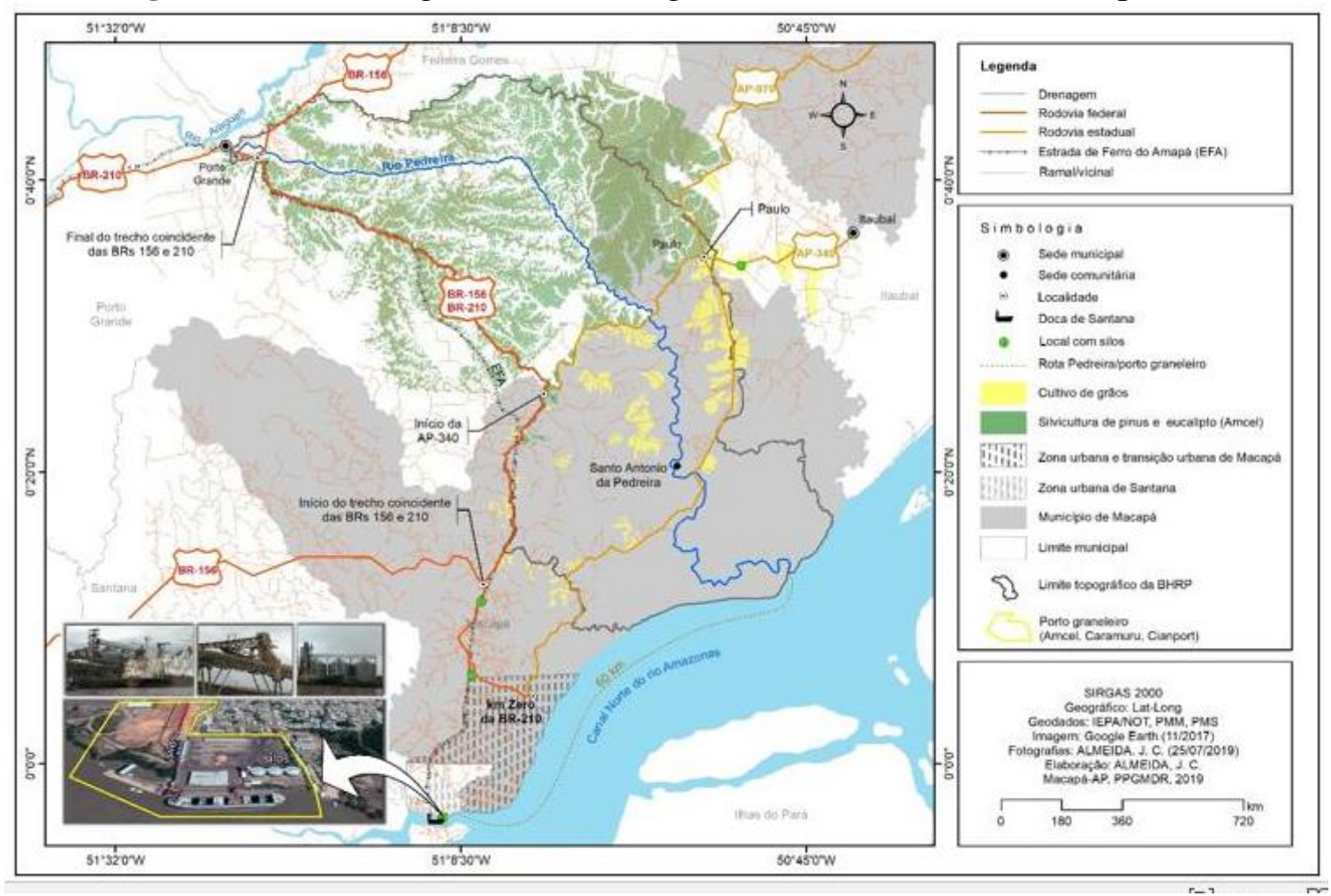

Fonte: Almeida (2020, p.102)

Cabe destacar que o processo de movimentação de commodities agrícolas (de soja) do estado do Amapá, deu-se a partir de 2012, com a primeira safra (MARGARIT, 2018), quando o Grupo Cianport ${ }^{14}$ e seu porto passam a exportar grãos. Empresa essa que possui capital social estimado de $\mathrm{R} \$ 122.501 .653,60$ e constitui braço "logístico alimentar" da Dakang ${ }^{15}$ Pasture Farming adquiere Fiagril Participações (possuindo 
como acionista controlador a Shanghai Pengxin ${ }^{16}$ ). Grupo chinês esse que em 2016 adquiriu 57,57\% do Grupo Fiagril (por mais de 290 milhões de dólares) e possui sede no estado do Mato Grosso.

Tal porto possibilitou a armazenagem e fluidez territorial como também coesão territorial com o estado do Mato Grosso, principal produtor de commodities agrícolas do Brasil - como resultado pragmático da implementação do terminal graneleiro de Santana, segundo o Guia do Investidor do Governo do estado do Amapá, a área plantada de grãos desta unidade federativa saltou de 2,4 mil hectares, em 2012, para aproximadamente 20 mil hectares em 2018. Em termos comparativos conforme trabalho de Margarit (2018), a safra de soja no estado do Amapá em 2013 foi de 12.906 toneladas, em 2014 atingi 40.792 toneladas e em 2018 atingindo 53.770 toneladas.

De acordo com Almeida (2020), o município de Macapá é o maior produtor de soja do estado do Amapá. Entre 2015 a 2018, Macapá presenciou um vertiginoso aumento da territorialização do agronegócio, em termos de plantio, do qual concentrou 80,90\% de toda a áreas plantadas ou destinadas à colheita de soja no estado do Amapá. Em 2018, as áreas plantadas ou destinadas às colheitas de soja, no município de Macapá, totalizaram 14.380 ha. Isso equivale a 69,94\% da área plantada ou destinada à colheita de soja de todo estado do Amapá (Figura 3).

Figura 3: Áreas da monucultura (latifúndio) de grãos, Amapá

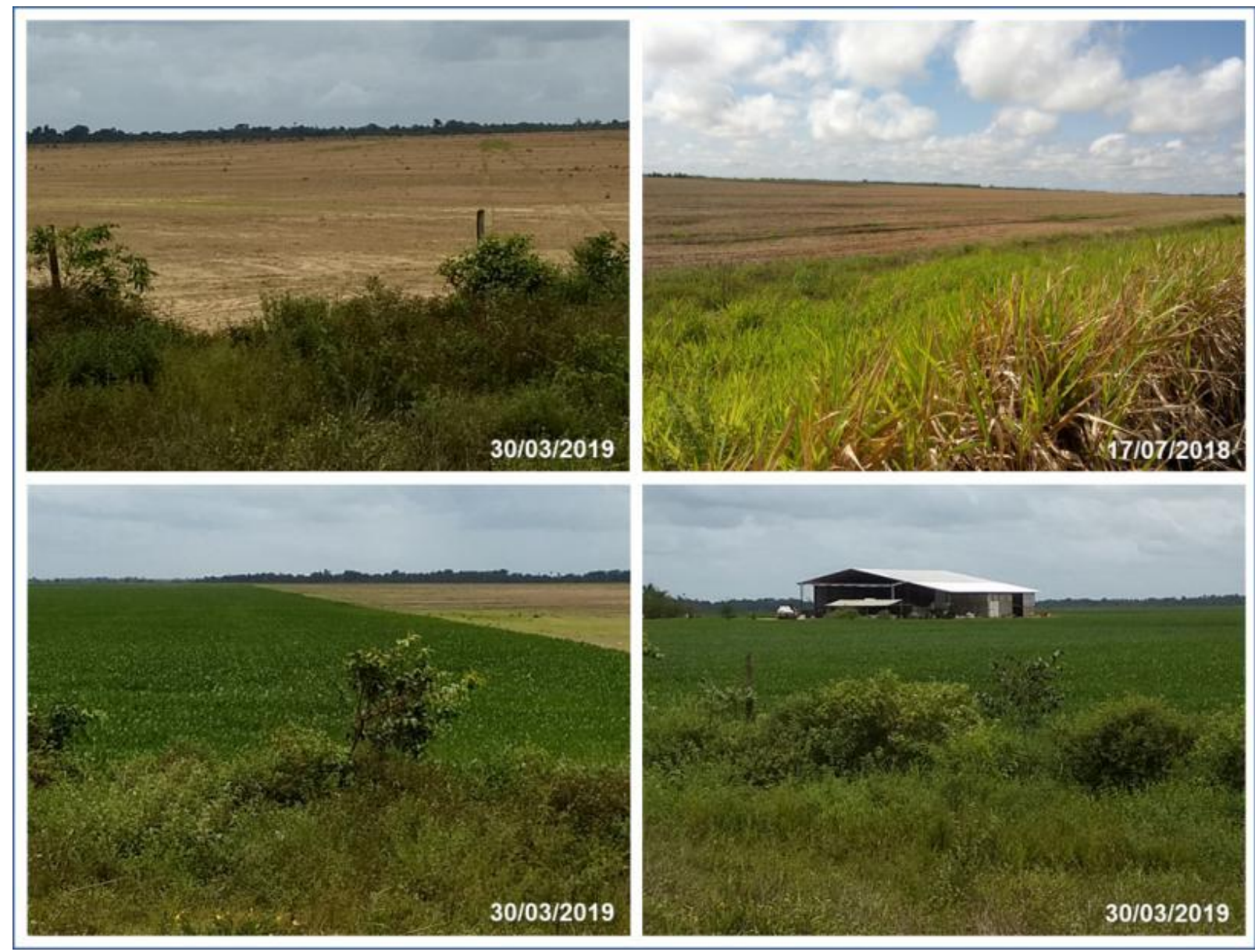

Fonte: Jodson Almeida (2019). 
Essa paisagem de monocultura e latifúndio estampado nos "campos" do estado do Amapá soma-se e contribui no processo de inserção de uma dinâmica de "competividade territorial", isto é, o

[...] uso de princípios concorrenciais e de competitividade intercapitalista (criada e utilizada no ambiente corporativo) na planificação e gestão dos territórios. São, portanto, concepções que se impregnam no território a ponto de se tornarem partes intrínsecas da sua estrutura de planejamento, investimentos e gestão. Os atributos da competitividade são absorvidos pelos agentes especuladores e produtores do território (SILVEIRA, 2020, p.47).

No caso do Amapá há um processo de construção de complexos portuários enquanto plataforma logística e célula produtiva e financeira global, para a conexão a cadeia de suprimentos e valor global do agronegócio. Tal configuração está expresso por agentes portuários que estão com terras reservadas e que solicitaram autorização de licenças a Agência Nacional de Transportes Aquaviários (ANTAQ) (Quadro 1):

Quadro 1: Portos planejados no Complexo Portuário de Santana (Macapá e Santana)

\begin{tabular}{|l|c|}
\hline Porto & Município \\
\hline Porto Ipiranga & Santana \\
\hline Porto Itaipava & Santana \\
\hline Porto Reicon & Santana \\
\hline Cianport II (Ilha de Santana) & Santana \\
\hline Porto Norte Brasil & Macapá \\
\hline Plataforma Logística do Amapá & Santana \\
I/combustível & \\
\hline Plataforma Logística do Amapá II/grãos & Santana \\
\hline
\end{tabular}

Fonte: elaborado a partir de http://portal.antaq.gov.br/ e por solicitação via sistema e-SIC

Tais portos, denominado de Complexo Portuário de Santana, dialogando com Rodrigues e Lima (2020), vem compor uma logística internacional das cadeias de suprimento e valores globais. Ainda para os autores há um tipo que se entrelaça a logística e aos "portos do agronegócio" que é o

"porto alimentador", isto é, portos de combustíveis que se conectam com a fluidez econômica global, abastecendo carretas, barcaças e empresas portuárias. No caso de Santana, no estado do Amapá, a territorialização está ocorrendo pelo porto do grupo Itaipava e Terminal de Granéis Líquidos do Amapá [Plataforma Logística do Amapá I] (RODRIGUES; LIMA, 2020, p. 99).

É uma conjuntura que está sendo produzida para atender grandes agentes econômicos (multinacionais, bancos e fundos e países hegemônicos). Desta forma é clara a ação de ajustes espaciais, isto é, "a criação de condições para que o capital se manifeste e ganhe movimento no espaço" (COUTO, 2007, p. 26), assim como a atuação das práticas espaciais. Uma das formas de práticas espaciais que vem se arquitetando é: i) a formação do complexo portuário de Santana (envolvendo Santana, Mazagão e Macapá); ii) a manutenção permanente da AP-070 ("rodovia da soja/milho") para ágil circulação de "mercadorias", soja e milho. E do processo de regularização fundiária, iniciada em $2019^{17}$, isto é, do processo de transferência de terras da União para a escala estadual. Essa última prática espacial (de transferências de terras) que veio motivando a expansão/territorialização do agronegócio, em termos de plantio, apropriação de terras e 
com a abertura de um mercado fundiário (de terras) ligados a agentes e práticas imobiliárias rentistas e especulativas.

Esse avanço de grandes agentes do agronegócio, que tende a se expandir, principalmente a partir da aprovação, pelo senado federal, em maio de 2020 (em meio ao período crítico de pandemia da Covid-19), do projeto de lei que facilita a transferência definitiva de terras pertencentes à União para os estados de Roraima e Amapá (PL 1.304/2020), que se torna Lei Ordinária, Lei no 14.004, de 26 de maio de $2020^{18}$.

Tal lei aponta que "preferencialmente" as terras deverão ser utilizadas em: I atividades agropecuárias diversificadas; II - atividades de desenvolvimento sustentável, de natureza agrícola ou não; III - projetos de colonização e regularização fundiária, na forma prevista na respectiva lei de terras dos Estados de Roraima e do Amapá. Junto a isso se estima que haja a transferência de 4,5 milhões de hectares de posse da União para o Governo do Amapá. Com isso, criando uma perspectiva de regularização da posse de terras pelos produtores e o acesso a financiamentos para a produção agrícola (vide em Almeida (2020), as porções territoriais, em termos de glebas, que serão transferidas).

O interessante dessa lei (Lei $\left.\mathrm{n}^{\circ} 14.004 / 2020\right)$ e do lobby realizado por a agentes econômicos e políticos ligados a esse setor contrariam a narrativa do próprio setor, de que: o objetivo do setor é aumentar a produtividade nas propriedades privadas e a não expansão agrícolas para outras terras. Para isso, é recorrente o uso dos seguintes dados: entre 2004 a 2013, cresceu $300 \%$ a produtividade de grãos e a produtividade do gado, em 150\%, em Mato Grosso (BRANDO et al, 2020). Tal narrativa construída como forma de se defender acerca da responsabilidade sobre os desmatamentos e incêndios (em 2019 e 2020) na Amazônia; que, aliás, tais desmatamentos e incêndios, como é sabido, são para atender a expansão da pecuária e de plantio de soja e milho (STABILE et al, 2020). É válido assinalar de que de 1985 a 2018, as pastagens e áreas de cultivo substituíram cerca de 65 milhões de hectares de florestas e savanas da Amazônia legal (STABILE et al, 2020). Cabe destacar também que segundo estudos de Rajão et al (2020), 2\% das propriedades na Amazônia e Cerrado e ligados ao agronegócio são responsáveis por $62 \%$ de todo o desmatamento ilegal. Além disso, cerca de $20 \%$ das exportações de soja e pelo menos $17 \%$ das exportações de carne bovina de ambos os biomas que estão indo para a União Europeia estão ligados ao desmatamento ilegal.

Ainda nesse contexto (quadro) há a intensificação do processo de produção de mercado de terras e de land grabbing, isto é, a estrangeirização de terras, na Amazônia Oriental (que inclui a produção de complexos portuários), com o controle de grandes extensões de terras, por meio da aquisição/compra, grilagem, arrendamento e/ou concessão de terras, a qualquer pessoa ou entidade (pública ou privada, estrangeira ou nacional), por qualquer meio ( "legal" ou "ilegal"), para fins de especulação, extração, controle de recursos ou mercantilização às custas de camponeses, pequenos(as) agricultores(as), da agricultura ecológica e da soberania e segurança alimentar e de direitos humanos, não-humanos e da natureza (BURJA; TAMAS-SZORA; DOBRA, 2020). O estado do Amapá certamente se insere nesse contexto de estrangeirização de terras, principalmente com a produção de complexos portuários e com a Lei $\mathrm{n}^{\circ}$ 14.004/2020.

Cabe destacar que, apenas aproximadamente $12 \%$ de terras do planeta são terras agrícolas e desse percentual mais da metade de toda a biomassa extraída são usadas globalmente por humanos (DURO et al, 2020). Além disso, há um processo acelerado de "infertilização de terras" face degradação do solo, lixiviação de pesticidas e nutrientes e perda de biodiversidade. Por isso, a busca desenfreada por terras agricultáveis (produção de mercado e latifúndio de terras) e produção da terra enquanto um ativo financeiro (financeirizado). 
Dialogando com Costa (2016, p. 2) trata-se:

[...] de mudanças associadas aos movimentos e às configurações particulares de maior complexidade nesse quadro de dispersão de fluxos e de aparente fragmentação do território nacional. Tal é o caso do acelerado processo de especialização das regiões, das sub-regiões e dos lugares, cuja maior intensidade é mais facilmente observável nas áreas metropolitanas, nos diversos aglomerados urbanos em fases de expansão e consolidação, nos eixos de desconcentração industrial e nas fronteiras agrícolas e pecuaristas do Centro-Oeste expandido e de algumas sub-regiões situadas nas franjas da Amazônia Oriental, Ocidental e Meridional.

Tais mudanças e perspectivas de transformações estão explícitas em diversos planos, programas de logística e investimentos, os quais "permitam identificar e representar os principais movimentos, forças e vetores que impactam as regiões e os lugares" (COSTA, 2016, p. 4). O ordenamento territorial insere-se nesse contexto, pois ele passa a ser, "entendido como instrumento estratégico na ordenação das ações socioespaciais não deve ser tomado como o atributo de uma dada forma de governo que, em um dado espaço-tempo, o transformou num instrumento autoritário" (COSTA, HIRT, 2011, p.3). Assim, as mudanças e perspectivas de transformações, bem como de ordenamento territorial, resultaram na implementação, transformação e inserção do Complexo Portuário de Santana na cadeia logística, nacional e internacional, como gestor e articulador de fluxos.

\section{Complexo Portuário de Santana e produção territorial}

O Complexo Portuário de Santana (CPS) está dentro do município de Santana (localizada no sudeste do estado do Amapá); região metropolitana de Macapá (mas, o complexo engloba o município de Mazagão e Macapá enquanto política territorial e geopolítica estratégica). A produção do CPS constitui uma arquitetura institucional (organizacional e regulatória) como também se perfaz pela captura e controle de territórios e discursos, a partir da monomentalidade de se inserir a globalização, a pauta exportadora e na perspectiva de progresso alicerçado no consumo insaciável e crescente. Assim vinculando os objetos técnicos, ações e políticas, que supostamente seriam decisões coletivas e participativas, para se criar:

1) um arranjo político e competividade territorial comum;

2) um discurso homogêneo de geopolítica estratégica;

3) de disputas econômicas e políticas por protagonismo e pelos ganhos simbólicos e materiais da concretização de território transnacionalizado, que também suspostamente promoveria ganhos coletivos e societários.

O município de Santana possui uma população estimada de 123.096 pessoas (estimativa do IBGE, de 2020); e, ao mesmo tempo tal população (em sua maioria) possui uma narrativa pinçada, ou, aliás, legitimada e fabricada por elites locais e regionais (e pelo Estado) de progresso e desenvolvimento ${ }^{19}$ (Vide figura 4 a seguir).

Além disso, insere-se na grande área do estado Amapá que possui uma área significativa de plantio de soja e milho e pode aumentar ainda mais, com a transferência de terras da união ao estado do Amapá e o processo de regularização fundiária, a partir da lei anteriormente discorrida por nós. Por fim, destacar-se-ia pela proximidade física com os maiores mercados consumidores mundiais, de commodities agrícolas/grãos (com base em 2019, vide http://web.antaq.gov.br/ANUARIO/): China, Alemanha, Rússia, Espanha, Japão, Portugal e Holanda (Figura 5). 
Figura 4: A narrativa de progresso dispersado no Amapá e pela Companhia Docas de Santana
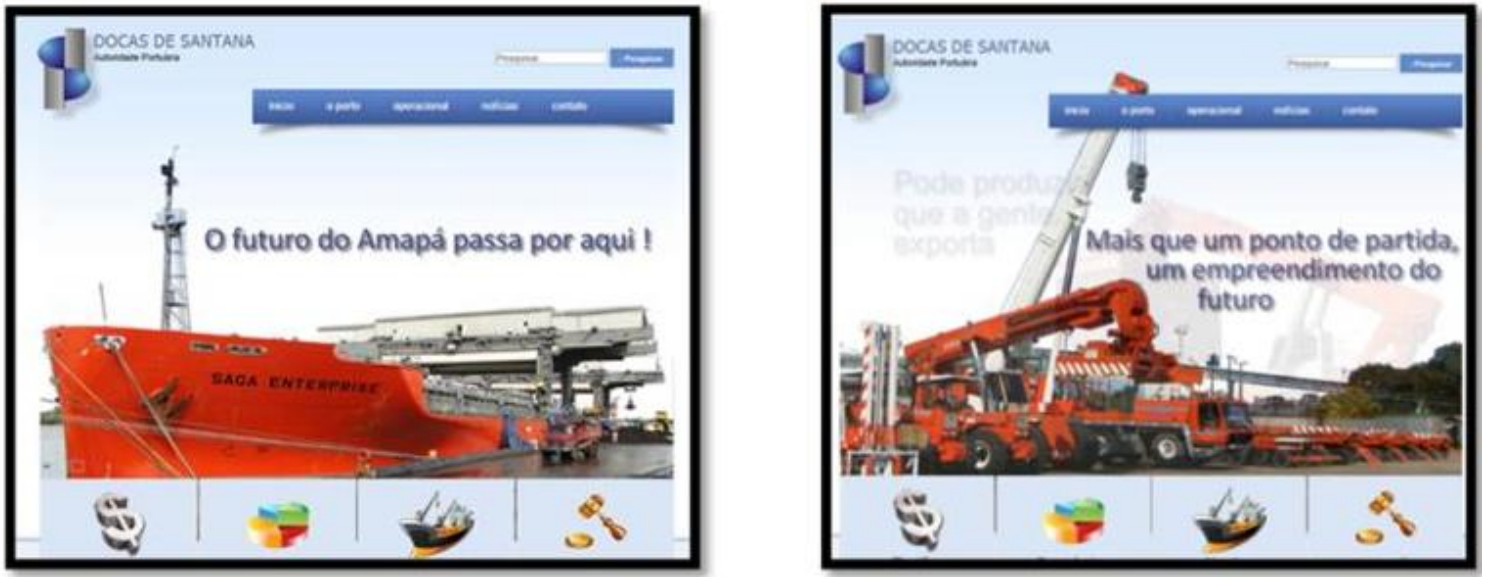

Fonte: http://www.docasdesantana.com.br/index.php

Figura 5: Localização Complexo Portuário de Santana, Santana, Amapá

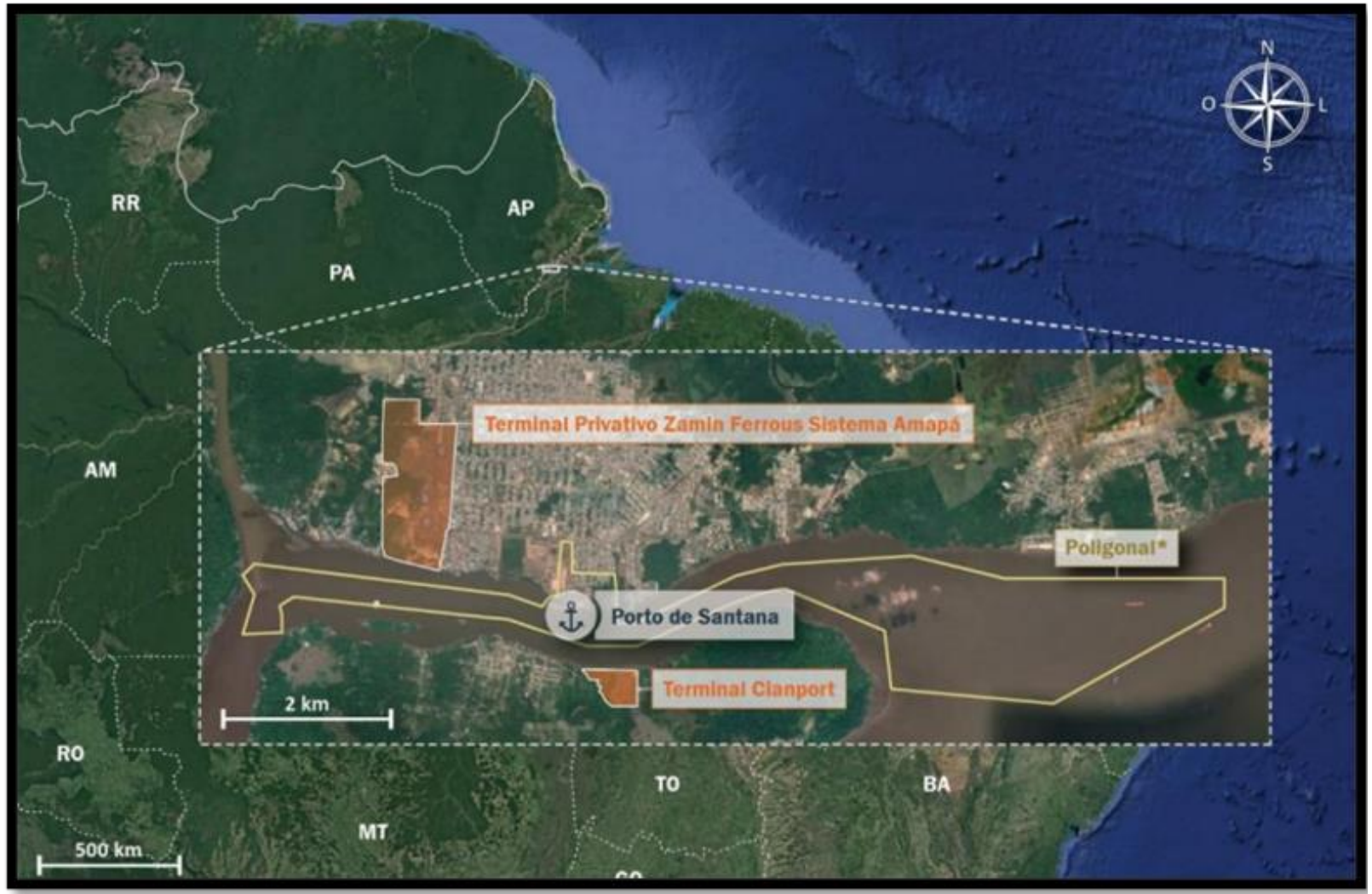

Fonte: Adaptado de Brasil (2017, p.11).

A figura 5 apresenta a localização do CPS, definido pelo Plano Mestre do Complexo Portuário de Santana, elaborado pelo Ministério dos Transportes, Portos e Aviação Civil, por meio da Secretaria Nacional de Portos, em 2017. Caracterizando a situação geográfica e apresentando as seguintes instalações portuárias: i) o Porto de Santana, situado na margem esquerda do Rio Amazonas, no canal de Santana, em frente à Ilha de Santana; ii) o Terminal Privativo Zamin Ferrous Sistema Amapá, situado a 2 km a montante do Porto de Santana; e, iii) o Terminal de Uso Privativo Cianport, que ainda 
se encontra em fase de projeto, e será instalado na Ilha de Santana, em frente ao Porto de Santana, na margem oposta do Rio Amazonas.

É relevante destacar que já houve novos adicionamento de agentes econômicos ao CPS assim como a configuração espacial e conceitual do porto de Santana. Recentemente não é mais considerado um porto, e sim complexo portuário, que denominamos de CPS, já que há vários portos dentro de um porto e também possuem um denso sistema técnico e informacional compartilhado, realizando o uso corporativo do território (privado e privatizado); e, também possuindo um forte mecanismo de segurança (jurídica e física) e pressão política (lobby) em escala local. Esse complexo hoje é composto pelos portos da Cianport, da Caramuru Alimentos e Amcel $^{20}$ (Figura 6).

Figura 6: fotos do porto da Cianport e Caramuru Alimentos
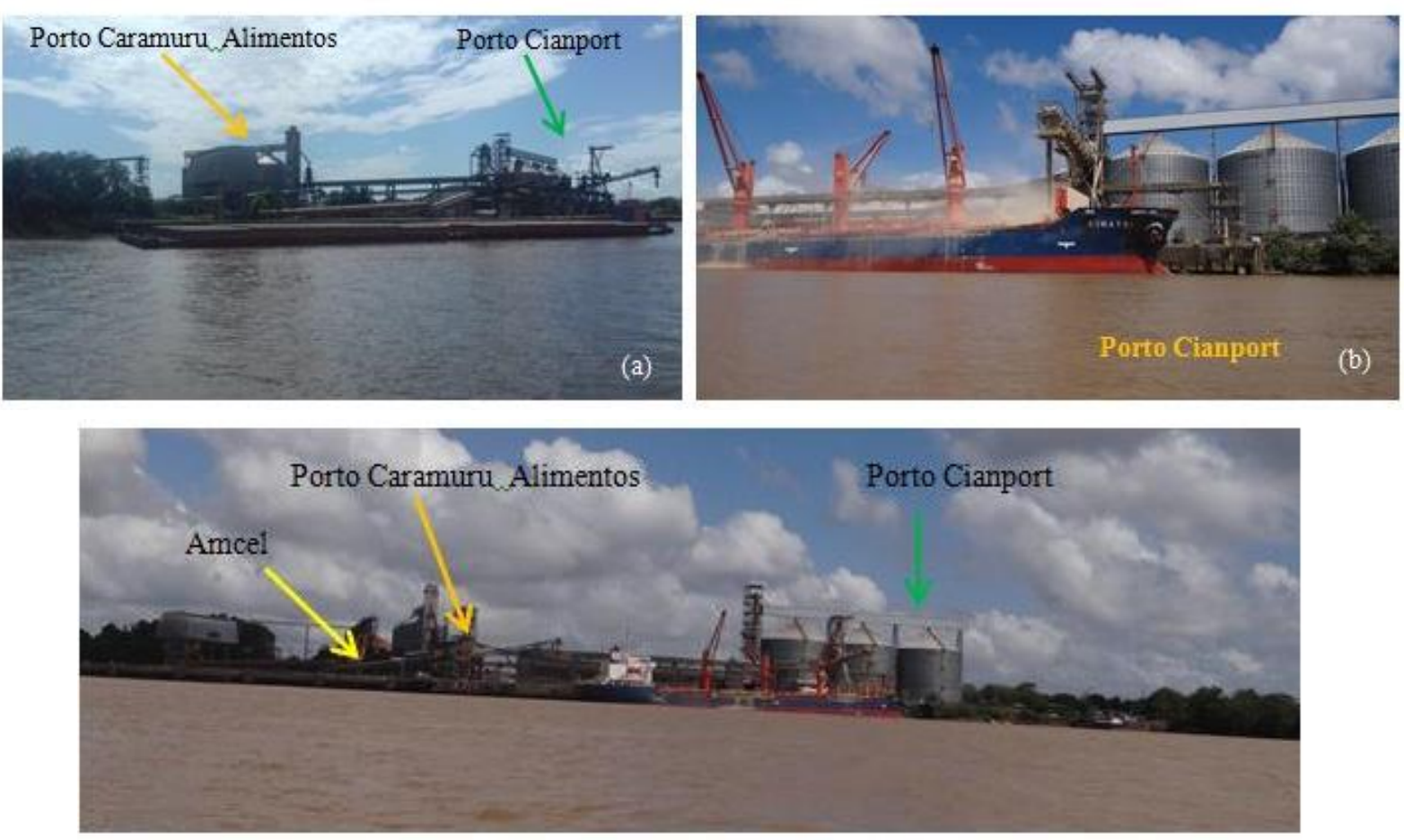

Fonte: registrado por J. R. Foto (a) registrada dia 24 de julho de 2019 e as fotos (b) e (c) foram registradas dia 20 dezembro de 2018

Observando a figura 5, Brasil (2017, p.61), destaca que o Complexo Portuário de Santana cobriria uma parte significativa do bairro Novo Horizonte (Figura 7 e 8). Esse bairro conforme o censo 2010, do Instituto Brasileiro de Geografia e Estatística (IBGE), sua população seria de 3.095 residentes e com 712 domicílios particulares permanentes, do qual 65.6\% (2.030) são de pessoas de 15 a 64 anos, cuja dependência total dos jovens é de 52,4\%. Dados esses logicamente subrepresentativos, já que com a construção e operação do porto da Cianport houve uma migração acentuada para diversos bairros; particularmente para bairro Novo Horizonte e a Ilha de Santana, em busca de empregos. 
Figura 7: Bairro Novo Horizonte, município de Santana, Amapá

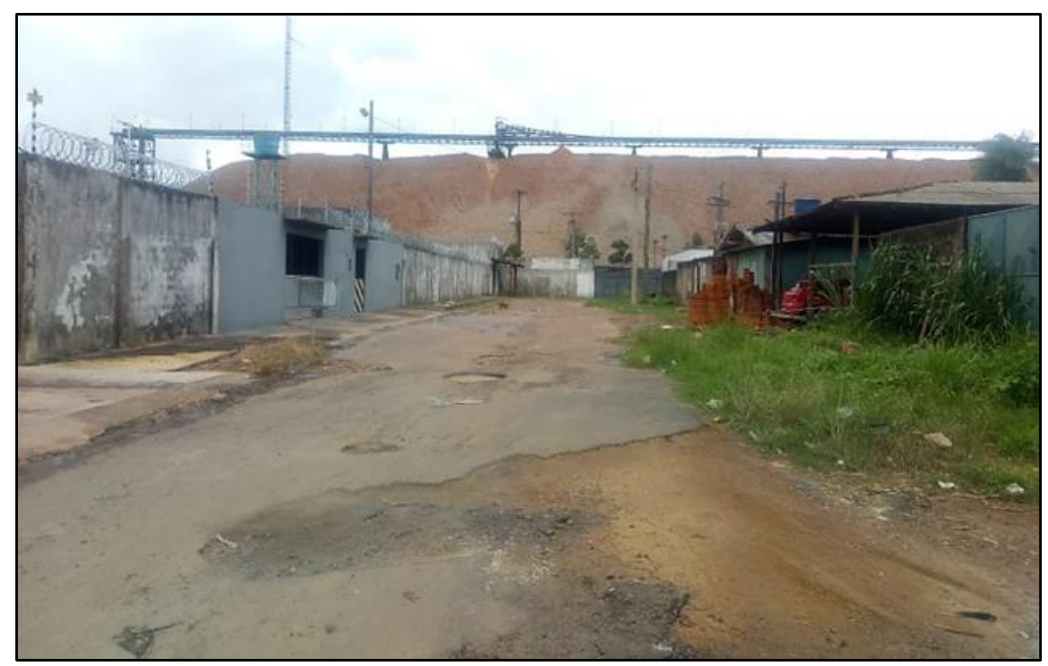

Fonte: Acervo dos autores

O bairro Novo Horizonte é "resultado" de um processo formação socioespacial, do qual os moradores foram excluídos dos dividendos econômicos e sofreram pelo uso privado de uma porção territorial, por exemplo, do rio e de ruas; como também de projetos de compensação e mitigação face impossibilidade de interação com rio, a poluição devido à poeira de celulose da empresa Amcel e de farelo de soja da Cianport ${ }^{21}$. Além da desigualdade socioespacial e violência urbana, os moradores ainda estão no contexto de conflitos territoriais pelos motivos já citados, como também, pela mobilidade de pessoas e trabalhadores que ali foram morar e lutam por direitos a moradia. Um exemplo concreto está expresso no caderno de Conflitos no Campo no Brasil, realizado pela Comissão Pastoral da Terra (CPT), do qual houve a identificação de conflitos por terra, em 2019, na ilha de Santana, envolvendo 20 famílias (CPT, 2020a), algo não presente no ano de 2018, nos dados do Cadernos de Conflitos no Campo (CPT, 2019).

O documento, no caso, o Plano Mestre do Complexo Portuário de Santana, afirma que tais mudanças trarão benefícios para a atividade portuária e para a população do entorno. Entretanto, não foram identificados projetos ou ações mitigatórias que contribuam para a resolução dos conflitos referente ao uso da área ocupada pela comunidade que ainda se mantem dentro da poligonal (Figura 8).

Como também tal Plano já aponta antecipadamente o processo de reintegração de posse da área, com isso aumentando a "tensão estrutural" (MOREIRA, 2001) e um processo de insegurança territorial e de ameaças de despejos (despossessões, nos dizeres de David Harvey). Cabe destacar que foi realizado um encontro, no dia 04 de novembro de 2019, entre Prefeitura de Santana e moradores do bairro Novo Horizonte, do qual foi apresentado o Projeto de regularização do bairro (Regularização Urbana por Interesse Social/REURB-S ${ }^{22}$ ) para concessão de título de posse aos 445 móveis ${ }^{23}$.

Todavia, o Plano Mestre do Complexo Portuário de Santana e a Nota Técnica Ministério de Infraestrutura (Ato Jusificatório para a modelagem do Programa de Arrendamentos Portuários do Governo Federal; Licitação da área MCP02 no Porto Organizado de Santana/AP) não há problemas e conflitos fundiários e passivo ambiental. Segundo a Nota Técnica afirma que: "segundo a análise documental, características/localização da área de estudo e vistoria in loco é possível afirmar que não foi identificado passivo ambiental" (BRASIL, 2019b, p. 20).

Além disso, não há qualquer descrição das áreas e bairros que estão fora das poligonais (por exemplo, a Ilha de Santana, do qual há o projeto da construção do Porto 
Cianport II), com isso desconsiderando efeitos irrradiativos e sinergéticos de projetos ou empreendimentos: i) mobilidade de trabalhadores (migração) e inchaço populacional; ii) violência urbana e conflitos fundiários; iii) deslocamento compulsórios/expulsões; iv) prostituição e tráfico de drogas; vi) estrangulamento dos serviços públicos de saúde, educação e transporte coletivo; vii) apropriação privada de estradas e ruas.

Há, portanto, a supressão sobre descrições acerca dos efeitos irrradiativos e sinergéticos, aliás, constitui uma prática recorrente da produção de complexos portuários na Amazônia, por exemplo, Barcarena, Itaituba e Rurópolis (RODRIGUES, 2018a; 2018b; RODRIGUES; RODRIGUES; LIMA, 2019) e São Luís (SANT'ANA JÚNIOR; TEISSERENC; BRUSTOLIN, 2018).

Figura 8: Poligonal do Complexo Portuário de Santana.

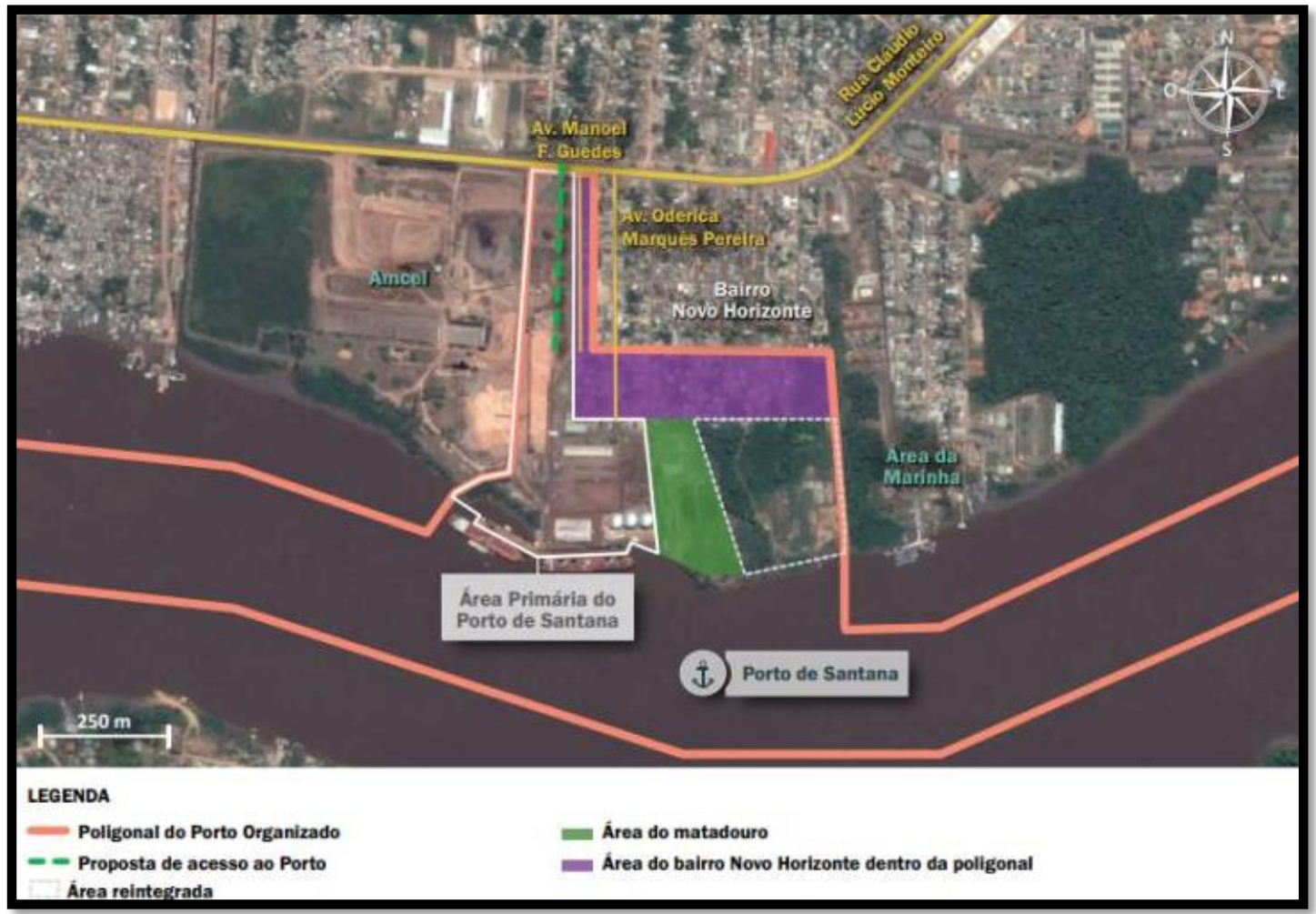

Fonte: Brasil (2017)

Ainda com relação ao Plano Mestre, percebe-se que ele não diz que benefícios serão obtidos (assim como as políticas territoriais e ações antecipativas espaciais do poder público) à população que residem no bairro Novo Horizonte, na Ilha de Santana e da população como todo do município de Santana. São ações e políticas territoriais que ignoram esta complexidade da vida social e segmentos sociais vulnerabilizados e incentivam a "individualização do laço social, [com] a personalização dos significados e valores induzem o distanciamento dos outros e da proteção que eles poderiam oferecer" (LE BRETON, 2019, p. 37). Sendo políticas que não são sequer paliativas e setoriais, mas sim classistas hegemônicas, no caso, seletiva e colonial.

Colonial ao reduzir a densidade do que seria lugar para essas pessoas, isto é, "[...] espaço percebido e vivido, dotado de significado e com base no qual desenvolvem-se, extraem-se os 'sentidos de lugar' e as 'imagens de lugar"' (SOUZA, 2018, p.114); como também onde se materializa o conteúdo e o valor simbólico que seria a história e a memória $^{24}$ da construção desse lugar. Conteúdo e valor simbólico "materializado"/expressos, por exemplo: i) nas relações de parentesco, de gênero e de 
reciprocidade entre vizinhos (ZHOURI, 2019); ii) do significado de conquista (casa/moradia); iii) da colaboração e solidariedade em comunidade, como também de identidade baseado vínculos históricos, sociais e familiares; iv) na história de perseverança, de alegrias, risos e também de choros que compuseram a construção de um bairro, de uma comunidade, um território e de uma moradia; e, v) de dimensão afetuosa e de extensão corporal no que tange a esse lugar.

Portanto, tal lugar não poderia ser materializado em outros espaços, como pensam o Estado e as empresas, quando entendem que com a indenização as pessoas poderiam morar em locais melhores. Assim esses dois agentes não apenas apequenam e inferiorizam o valor simbólico e cultural, mas ocultam, invisibilizam e asfixiam as múltiplas formas de existência e territorialidades, e mercantilizam as relações sociais e reduzem o "lugar/local" a um mero objeto de compra/venda.

\section{Considerações Finais}

As duas últimas décadas foram marcadas por acelerados processos de financeirização da economia mundial, da neoliberalização da vida e de um processo de "modernização e seletividade espacial"; além das intensificações produtivistas e especializações especulativas que intensificam a tecnificação do território. Na Amazônia, esse cenário se estrutura, por meio, sobretudo, da implementação de políticas territoriais (ajustes espaciais, práticas espaciais e ordenamento territorial), que não só influenciaram na reconfiguração da paisagem, mas também resultaram em processos de contradições, desigualdades, conflitos e injustiça espacial e ambiental.

Processos contraditórios intensificados significativamente (recentemente e nessa última década) pelo agronegócio. Tais efeitos contraditórios são corroborados em pesquisas até mesmo pouco críticas como de Silva et al (2020), do qual destaca: o controle do "sistema agroalimentar global" (do agronegócio) por poucas empresas multinacionais ${ }^{25}$. Empresas essas que: i) afetam as decisões dos produtores; ii) limitam severamente o controle sobre insumos; iii) reduzem o poder de barganha no mercado; e, iv) dificultam o acesso ao crédito agrícola e outros recursos financeiros (SILVA et al, 2020). Ainda segundo Silva et al (2020) o modelo do agronegócio no Brasil aumentou o capital internacional, levou as propriedades a continuarem a crescer absorvendo propriedades menores, aprofundando a pobreza rural e diminuindo drasticamente as atividades de subsistência. Tudo como forma de diminuição da vulnerabilidade de ganhos econômicos do agronegócio, consequentemente no aumento de margens de lucros.

Cabe ainda destacar segundo o Atlas de Conflitos Socioterritoriais PanAmazônico (organizado pela Comissão Pastoral da Terra) o agronegócio representa, no Brasil, 60\% das causas de conflitos registrados e na pan-amazônia (que incluiu nesse Atlas: Bolívia, Brasil, Colômbia e Peru), e é responsável por $43 \%$ dos conflitos, bem como casos emblemáticos e sistemáticos de violação de direitos dos povos da região panamazônica (CPT, 2020b).

O que se verifica a partir de um olhar panorâmico espacial e histórico (na escala da Amazônia ou do estado do Amapá, analisado a partir da produção de complexos portuários) é que as ações políticas são criadas e/ou reajustadas, e o espaço/território é "ordenado" e transformado para um horizonte de cuidado, atenção, mobilidade, conforto, tranquilidade para os grandes agentes econômicos do capital (ligados ao setor do agronegócio, principalmente) e oferecidos em forma de cardápio, um "menu territorial", a serem escolhidos e comprados pelos clientes: apresentados com "potencialidades e oportunidades econômicas". Há um sincronismo entre lógicas capitalistas e lógicas territoriais, ajustes espaciais, práticas espaciais e ordenamento territorial e uma sinergia 
de (ações) políticas territoriais municipal, estadual e federal na produção de grandes objetos técnicos e produtivos/financeiros, no caso, complexos portuários.

Tal sincronismo associado à busca incansável, por segmentos políticos (que compõe o Estado), para debater e fomentar caminhos de abertura de portas de concessão de créditos ao setor logístico e portuário, por exemplo: a Audiência pública presidida e solicitada pelo senador Zequinha Marinho (PSC-PA), e ocorrida dia 18 de junho de 2019, em Brasília. Para o Senador: "A gente precisa trabalhar de forma pesada. Vamos atuar junto à Comissão de Orçamento, da qual sou membro, vamos conversar muito com o presidente da comissão, com o relator, para que a gente possa garantir, pelo menos, boa parte dos recursos de que nós vamos precisar para avançar com a logística do Arco Norte" (AGÊNCIA SENADO, 2019).

Cabe destacar que as territorializações por meio da produção de complexos portuários na Amazônia dialogando com os trabalhos de Rodrigues (2018a; 2018b), Rodrigues, Rodrigues e Lima (2019), Rodrigues e Hazeu (2019) e Rodrigues e Lima (2020) não se centram em si nesses "espaços" por serem fronteiras de recursos naturais ${ }^{26}$ (apesar de possuir grande peso $)^{27}$, mas, sobretudo, por serem uma "frente econômica". Frente econômica (formado por bancos, fundos, multinacionais, instituições multilaterais e países hegemônicos) essa que buscaria controle e monopólio espacial de infraestruturas "naturais" para competição global, devido: i) a proximidade física-natural com grandes mercados consumidores; ii) o uso de rios ou da multimodalidade; iii) áreas de terras com potencialidade de plantio e especulação (rentismo); iv) mão de obra barata; v) baixa ou nenhuma fiscalização; vi) incentivos fiscais e de financiamento; e. vii) apoio de elites políticas locais e regionais.

No caso, o município de Santana, vem sendo produzido para compor esse "horizonte", um polo de dinamização e de transformações seletivas no espaço (MONTEMOR, 2015) e para (atender) uma fração da sociedade (uma classe/agentes hegemônicos). $\mathrm{Ou}$, mais especificamente, por meio da produção de complexos portuários, há constituição de um "processo de reconstrução e desconstrução territorial notadamente privado e privatizador" (SANTOS; SOUZA; SILVEIRA, 1998, p. 12) e que entrelaça processos e escalas globais, nacionais e locais de produção e circulação.

Além disso, possuindo a tendência de ser cada vez mais uma plataforma e célula produtiva-especulativa, e, compor um corredor, por onde se esvai (extrai-se) valores e riquezas, dos quais são privadas. Todavia, impondo desvalorizações, contradições e espoliações a territórios (novas zonas de sacrifício $^{28}$ ) já vulneráveis por projetos (históricos) desenvolvimentistas.

\section{Notas}

1 - O presente artigo resulta do estágio de Pós-doutorado, no Programa de Pós-Graduação em Desenvolvimento Regional, da Universidade de Federal do Amapá, com apoio da Bolsa FAPEAP/CAPES. Também constitui o início da pesquisa de Jocianny Carla da Silva Sardinha, no mestrado em Geografia, da Universidade Federal do Amapá (UNIFAP).

2 - Aqui estamos pensando a Amazônia na sua multiplicidade e pluralidade de cores, cheiros, populações, comunidades, etnias, territorialidades, cosmovisões e formações socioespaciais. Portanto, não reduzindo a floresta amazônica como palco exclusivo e cenário de intensa destruição e reinvenção dos processos de produção social do espaço, como destacado por Monte-Mór (2015).

3 - "A urbanização extensiva pode ser definida como a forma sócio-espacial que expande as condições urbano-industriais de produção (e reprodução) por sobre o espaço regional articulando o urbano e o rural em uma única e (virtualmente) integrada forma urbana, carregando também consigo as especificidades de polis e da civitas: a práxis urbana, a política e a cidadania” (MONTE-MÓR, 2015, p. 115).

4 - Elaborado pelo Congresso Nacional - Câmara dos Deputados, mais especificamente o Centro de Estudos e Debates Estratégicos. Possuindo como consultor legislativo e coordenador-técnico do estudo sobre o Arco Norte Tarcísio Freitas, atual ministro da Infraestrutura do governo de Jair Bolsonaro. 
5 - Lobbies conformados por grupo de pressão que seriam grupo(s) de pessoas ou organização(ões) que teriam como atividade-fim a busca por "influenciar" (de diversas formas materiais e imateriais), aberta ou secretamente, decisões do poder público, especialmente do poder legislativo, em favor de determinados interesses privados.

6 - "ações que contribuem para garantir os diversos projetos. São meios efetivos através dos quais objetivase a gestão do território, isto é, a administração e o controle da organização espacial em sua existência e reprodução" (CORRÊA, 1995, p. 35).

7 - Outra forma de controle é a atuação nas operações financeiras. Para Paula, Santos e Pereira (2015, p. 299): "O efeito estabilizador de preços do mercado futuro, visando minimizar o risco e garantir a liquidez para os operadores do mercado físico, perdeu relevância com a entrada de investidores financeiros como bancos, fundos de hedge, fundos de pensão, investidores institucionais etc., transformando commodities em derivativos. A metamorfose de estoques físicos em papéis negociáveis acabou assim por criar uma interface do mercado físico com o sistema financeiro a partir da qual não somente países e regiões se articularam mais estreitamente, mas os estoques se converteram num instrumento de valorização do capital financeiro". "O capital financeiro criou, portanto, uma simbiose com as esferas produtivas e comerciais, contaminandoas com uma dinâmica específica de acordo com suas estratégias e expectativas, a exemplo dos index funds de commodities criados pelos bancos cuja rentabilidade e baixo risco aumentaram seus ganhos e atraíramos demais investidores" (op. cit, p.301).

8 - A Lei $\mathrm{n}^{\circ} 949$, de 18 de abril de $2012 \mathrm{em}$ si constitui uma forma especulativa e rentista das terras urbanas, via lotes, já que no artigo 123 enfatiza que os lotes teriam de possuir área mínima: $125 \mathrm{~m}$ (com frente mínima de $5 \mathrm{~m}$ e em esquinas de $12 \mathrm{~m}$ ), salvo loteamentos de interesse social coletivo.

9 - Tal porto possui como seu principal dono a megaempresa chinesa China Communications Construction Company (CCCC) (com participação em 51\% do empreendimento, e por sócios brasileiros da WPR, com 49\%). O projeto compreende uma área de 200 hectares (e 137, 95 hectares em área de espelho d'água). Pretende movimentar soja, milho, fertilizante, carga geral e derivados de petróleo (com terminais específicos de movimentação, no caso quatro) (MOREIRA; CASTRO; SANTOS, 2018). O projeto portuário pretende investir mais 2,6 bilhões de reais. Porém, onde vem sendo construído tal porto viviam muitas famílias (algumas delas já despejadas) e outras que ainda vivem (e ameaçadas de despejos) são comunidades e populações tradicionais (quilombolas, pescadores e agroextrativistas)..Um lugar múltiplas riquezas como florestas, animais e manguezais, cuja preservação é fundamental para a reprodução e a sobrevivência de inúmeras espécies de peixes, caranguejos e outros animais (contudo, está sendo desmatado e degradado). Moradores denunciam desde 2014 a destruição de casas e de roças, proibição de acesso a praia, ameaças de jagunços e toda sorte de dificuldades para seguir pescando e plantando (PEDRO; SANT'ANA JÚNIOR, 2018). Em 2017, cinco pessoas foram ameaçadas de morte, três da mesma família (BOURSCHEIT, 2019a; 2019b). "Hoje restam 34 pessoas das 250 que viviam ali originalmente. Apenas sete lotes ainda não foram reintegrados" (BOURSCHEIT, 2019b).

10 - Segundo Hocsman (2014): “(...) empresas transnacionales y actores locales [na Argentina] han configurado una nueva situación de dependencia, y han determinado la privatización y concentración de la economía con la explotación de los recursos naturales, la devastación de los ecosistemas y el mayor despoblamiento del campo. (...) Las cosechas récord se produjeron de forma simultánea a la profundización de la crisis agraria [y alimentaria] más importante de la historia [del país]. (...) La expansión del agronegocio orientado a la exportación se manifestó en la concentración de tierra, la utilización de transgénicos y agrotóxicos -con tecnología que degrada los suelos y destruye la riqueza natural de los bosques nativos, así como la diversidad de la producción campesina-, y la expulsión de los pobladores de sus tierras" (HOCSMAN, 2014, p. 55-6). Em outras regiões do Brasil tal cenário de contradições, conflitos, desmatamentos e degradação socioambiental não é diferente. Vide os trabalhos de: Spadotto e Cogueto (2019), Silva et al (2019), Almeida, Sodré e Mattos Junior (2019).

11 - Tal fragmento constitui um trecho do texto da Frente Parlamentar Mista em "Defesa dos Portos do Norte do Brasil", a pedido da Dep. Leda Sadala/AVANTE/Amapá. Tal Frente foi lançada dia 06 de novembro de 2019, na Câmara dos Deputados. O deputado federal Camilo Capiberibe (PSB-AP) e vicepresidente da frente têm como um dos objetivos incluir a modernização do Porto de Santana como prioridade na pauta de trabalho da Frente. Um dos objetivos da Frente é debater as dificuldades de investimentos e a potencialização dos portos localizados no Arco Norte e viabilizar os investimentos, públicos ou privados, requeridos para os portos do Norte do Brasil para os estados de Rondônia, Amazonas, Amapá, Pará e Maranhão.

12 - Em termos de preços por hectares, do qual utiliza o município de Macapá como parâmetro comparativo. 13 - A área plantada de grãos no estado Amapá cresceu substancialmente. Segundo Amapá (2019, p. 45): "a área plantada com grãos passou de 2,4 mil hectares em 2012 para aproximadamente 20 mil hectares em 2018" e "a produção, que era de menos de 8 mil toneladas há três anos, fechou 2017 com 50 mil toneladas". 
14 - A Cianport foi fundada em dezembro de 2011, por investidores nacionais (Fiagril Participações S.A. e Agro Soja Comércio e Exportações de Cereais Ltda), com experiência em comercialização e industrialização de grãos na região Centro-Oeste, em busca de alternativas para maior competitividade do agronegócio. Cabe assinalar que em 2012 a diretoria do BNDES aprovou financiamento de $\mathrm{R} \$ 75,9$ milhões para a Companhia Norte de Navegação e Portos S/A (Cianport). Os recursos, do Fundo de Marinha Mercante (FMM)

vide https://www.bndes.gov.br/wps/portal/site/home/imprensa/noticias/conteudo/20121220_hidroviario.

15 - Hunan Dakang Farming Co., Ltd possui duas estruturas de atuação (agricultura + alimentação) e cinco divisões de negócios principais (comércio de grãos, gado de corte, laticínios e ovelhas), cujo negócios se espalham-se principalmente pela China, Brasil, Nova Zelândia, Mianmar e Laos (vide: http://www.dkifa.com/en/overview.html).

16 - A Shanghai Pengxin (Group) Co., Ltd. foi fundada em 1988. É um grupo internacional de empresas privadas que integra novas energias, alimentos agrícolas, saúde e bens imóveis de saúde, conservação de energia e proteção ambiental e outras indústrias. Ela possui quatro empresas listadas, incluindo Pengxin Resources, Dakang Agriculture, Interchina Water e Runzhong International, com ativos de quase 100 bilhões de yuans. Por mais de 30 anos, o Grupo Pengxin seguiu de perto a estratégia nacional, aproveitou oportunidades de desenvolvimento, focou na indústria, focou no negócio principal e continuou a aprofundar os setores de negócios de novas energias, alimentos agrícolas, proteção ambiental e saúde. http://www.peng-xin.com.cn/about/introduce.html

17 - A Medida Provisória n ${ }^{\circ}$ 901, de 2019 é uma das grandes impulsionadoras (Transferência de terras da União a Roraima e Amapá).

18 - A transferência se dará com base no georreferenciamento dos limites das terras e nos destaques com a identificação das áreas excluídas, a serem feitos pela União no prazo de um ano a partir da publicação da lei. Caso a União não o faça, serão usadas as identificações dos destaques constantes da base cartográfica do Instituto Nacional de Colonização e Reforma Agrária (INCRA).

19 - Para Rodrigues e Lima (2020) vem sendo produzido uma narrativa progressista de desenvolvimento, isto é, "Uma enunciação e dispersão de palavras e discursos como verdade absoluta e inquestionável, uma espécie de "imperialismo/autoritarismo do universal": de construção de uma história a região e de neutralização do conceito histórico, como também para o apontamento (entenda aqui como obrigando, impondo) o caminho histórico a ser traçado e alimentado" (RODRIGUES; LIMA, 2020, p. 109). "Esse caminho 'imperialista' pauta-se (também) na narrativa de consumo da modernidade que é de colonialidade, progressista e correspondem à retórica celebratória da modernidade (MIGNOLO, 2017b, p. 4) [...], e que seria o projeto ético, moral e político 'para' as populações e regiões (com a retórica de vocação e potencial natural e posição/local estratégico para o desenvolvimento, visualizado nos discursos de segmentos empresariais e estatais, no estado do Pará e Amapá)" (RODRIGUES; LIMA, 2020, p. 110).

20 - A empresa Amcel - Amapá Florestal e Celulose S.A apresenta-se no seu site institucional (http://www.amcel.com.br/\#about/) como empresa brasileira de manejo florestal sustentável, cujo objetivo é reflorestar, processar e exportar cavacos de eucalipto, para suprir de matéria-prima a indústria de celulose, papel e produtos de madeira. Foi criada em agosto de 1976 como subsidiária do Grupo CAEMI, iniciando os plantios de Pinus em 1977. Em 1996, a Champion Papel e Celulose adquiriu os direitos acionários da Amcel e em 2000 a International Paper do Brasil Ltda., assumiu o grupo Champion. Em 2004, a empresa optou pela substituição dos plantios de Pinus spp. por Eucalyptus spp. Atualmente o controle acionário da AMCEL pertence aos Grupos Japoneses, Nippon Paper Industries e NYK - Nippon Yusen Kabushiki Kaisha. A Amcel possui sob sua propriedade fundiária cerca de 130 mil hectares disponíveis para o plantio de florestas renováveis de eucalipto somados a 180 mil hectares de reservas nativas, o projeto florestal abrange sete municípios do estado do Amapá: Santana, Macapá, Porto Grande, Ferreira Gomes, Itaubal do Piririm, Tartarugalzinho e Amapá.

21 - A Companhia Docas de Santana (CDSA) diz que há um projeto, porém, algo pontual (e que finalizou) que é o "CDSA de mãos dadas com o esporte e a educação" (BRASIL, 2017). O projeto segundo Brasil (2017, p. 101): "beneficiava cerca de 150 crianças do bairro Novo Horizonte, com aulas de idiomas, reforço escolar, atividades esportivas, café da manhã nos dias de atividade e cesta básica mensal para as famílias das crianças participantes. O projeto era custeado, integralmente, pela CDSA e foi paralisado no final de 2015 por falta de recursos e insucesso na tentativa de parcerias com o Governo Estadual e Federal para continuação das atividades".

22 - A regularização fundiária (a política fundiária urbana) do bairro Novo Horizonte sustenta-se, no discurso da prefeitura de Santana, na Lei ${ }^{\circ}$ 13.465/ 2017 (Dispõe sobre a regularização fundiária rural e urbana, sobre a liquidação de créditos concedidos aos assentados da reforma agrária e sobre a regularização fundiária no âmbito da Amazônia Legal). Mais precisamente, no seu Art. 9': "Ficam instituídas no território nacional normas gerais e procedimentos aplicáveis à Regularização Fundiária Urbana (Reurb), a qual abrange medidas jurídicas, urbanísticas, ambientais e sociais destinadas à incorporação dos núcleos urbanos 
informais ao ordenamento territorial urbano e à titulação de seus ocupantes”. No caso tal regularização se enquadrando no Reurb de Interesse Social (Reurb-S) - "regularização fundiária aplicável aos núcleos urbanos informais ocupados predominantemente por população de baixa renda, assim declarados em ato do Poder Executivo municipal".

23 - Tal regularização fundiária não está separada de uma ação política, isto é, de um "sistema político estruturado para gravitar em torno do poder central", já que "na atualidade, as políticas públicas territoriais na escala nacional tendem à fragmentação, isto é, correspondem (e reiteram), de um lado, à crescente especialização dos aparelhos do Estado e à setorização dos planos, programas e projetos" (COSTA, 2016, p. 1). Tal ação de regularização, em certa dimensão, "poderia" apontar ou significar uma forma de regularizar e conceder títulos de posse para posteriormente haja a possibilidade de articular com maior agilidades as indenizações e remoções de populações das áreas.

24 - Para Pollak (1992, p. 204): “a memória é um elemento constituinte do sentimento de identidade, tanto individual como coletiva, na medida em que ela é também um fator extremamente importante do sentimento de continuidade e de coerência de uma pessoa ou de um grupo em sua reconstrução de si”.

25 - Para Wesz Jr (2016) as principais empresas que atuam nos últimos elos da cadeia produtiva são a ADM (Archer Daniels Midland), a Bunge, a Cargill e a Dreyfus (empresas da ABCD), líderes globais no comércio de commodities. Seriam “impérios alimentares" (PLOEG, 2019): “Son redes oligopólicas operadas a nivel global, que controlan partes importantes y en expansión de los procesos de producción, procesamiento, distribución y consumo de alimentos" (PLOEG, 2019, p. 167). Ainda para o mesmo autor "Los imperios (y los imperios alimentarios en particular) no sólo buscan el control, también buscan apropiarse y centralizar el valor" (p. 168), isto é, "os imperios alimentarios se convierten cada vez más en una potencia extraeconómica capaz de configurar y gobernar determinados mercados. Convierten el acceso, el derecho a producir, la posibilidad de vender y la atribución de cualificaciones (por ejemplo, a través de la certificación y la acreditación) en un sinfín de nuevos productos" (p. 168).

26- Fronteira é entendida aqui (nesse parágrafo) como áreas como fontes abundantes de recursos naturais, ou seja, seria considerada área de amplo extrativismo. Extrativismo (produção/degradação e exportação) que possuiria duas dimensões inseparáveis: de controle do monopólio sobre recursos naturais específicos (minerais, petróleo, gás, terras férteis, aquíferos, florestas, monocultura de grande escala) e resulta em sua exploração implacável (YE et al, 2020).

27 - Cabe destacar de Itaituba e Barcarena onde há muitos portos do agronegócio operando e planejados, porém não há áreas de plantios de soja e milho.

28 - Novas zonas de sacrifício seriam as novas áreas, ou, mais particularmente, territórios, que passam a compor a célula de extração, exploração e expropriação para desenvolvimento social e econômica de outras regiões e países ou elites, bancos, fundos e/ou multinacionais.

\section{Referências}

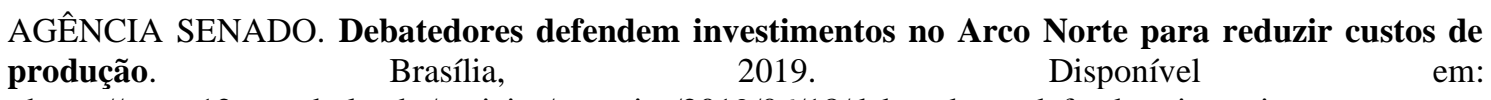
<https://www12.senado.leg.br/noticias/materias/2019/06/18/debatedores-defendem-investimentos-noarco-norte-para-reduzir-custos-de-producao>. Acesso em: 07 fev. 2020.

ALMEIDA, J. C. Fronteira agrícola na Amazônia: análise da dinâmica do uso múltiplo da bacia do Rio Pedreira no Estado do Amapá. Macapá, 2020. 145 f. Dissertação (Mestrado em Desenvolvimento Regional) - Universidade Federal do Amapá, Programa de Pós-Graduação em Desenvolvimento Regional, Macapá, 2020.

ALMEIDA, J. G.; SODRÉ, R. B.; MATTOS JÚNIOR, J. S. O MATOPIBA nas Chapadas Maranhenses: Impactos da Expansão do Agronegócio na Microrregião de Chapadinha. Revista NERA, v. 22, n. 47, p. 248-271, 2019.

BOURSCHEIT, A. Sitiados pelo progresso. Amazônia, notícias e informações. 2019. Disponível em: <https://amazonia.org.br/2019/05/sitiados-pelo-progresso/>. Acesso em: 07 fev. 2020.

BOURSCHEIT, A. Conflito entre megaporto China-Brasil e comunidade tradicional se agrava. Diálogo Chino, 2019b. Disponível em: <https://dialogochino.net/30162-sao-luis-megaport-conflictintensifies/?lang=pt-br>. Acesso em: 07 fev. 2020.

BRANDO, P. et al. Amazon wildfires: Scenes from a foreseeable disaster. Flora, v. v. 268, p. 1-5, 2020. BRASIL. Ministério dos Transportes, Portos e Aviação Civil. Secretaria Nacional de Portos. Plano Mestre: Complexo Portuário de Santana. Brasília: 2017.

BRASIL. Requerimento de instalação de frente parlamentar. Disponível em: <https://www.camara.leg.br/proposicoesWeb/prop_mostrarintegra;jsessionid=7F060F078A15F76066C9F 20838195CD7.proposicoesWebExterno2?codteor=1776681\&filename=Tramitacao-REQ+1926/2019>. Brasília: Câmera dos Deputados, 2019a. 
BRASIL. Nota Técnica $\mathbf{N}^{\mathbf{0}}$ 112/2019/CGMP/DNOP-SNPTA/SNPTA. Brasília: Ministério de Infraestrutura, 2019b. Disponível em: <http://web.antaq.gov.br/Sistemas/WebServiceLeilao/DocumentoUpload/Audiencia\%2048/ATO_JUSTI FICATAT\%C3\%93RIO.pdf>. Acesso em: 03 fev. 2020.

BRASIL. CÂMARA DOS DEPUTADOS. Arco Norte: o desafio logístico. Brasília: Câmara dos Deputados/Edições Câmara, 2016.

BURJA, V.; TAMAS-SZORA, A.; DOBRA, I.B. Land Concentration, Land Grabbing and Sustainable Development of Agriculture in Romania. Sustainability, v. 12, p. 1-19, 2020.

CARMO, E. M. A.; BARREIRA, C. C. A.; MIRANDA, C. P. Os mecanismos de consenso e coerção em torno do projeto de desenvolvimento hegemônico no Amapá. PRACS: Revista Eletrônica de Humanidades do Curso de Ciências Sociais da UNIFAP, v. 13, n. 2, p. 253-270, 2020.

CASTRO, E. M. R. Amazônia na encruzilhada: saque colonial e lutas de resistência. Territórios em transformação na Amazônia - saberes, rupturas e resistências. In: CASTRO, E. M. R. (Org.). Belém: NAEA, 2017. p. 19-48.

CASTRO, E. M. R. Pan-Amazônia refém? Desenvolvimento nacional e regional. In: CARLEIAL, L. M. F.; CRUZ, B. O.; CASTRO, E. M. R. (Org.). O desenvolvimento regional brasileiro. Questões em debate. São Paulo: HUCITEC, 2018, v. 1, p. 186-2010.

CHELALA, C.; CHELALA, C. Soja no Amapá: história, economia e meio ambiente. São Paulo: Clube dos Autores, 2019.

CLAVAL, P. Marxismo e geografia econômica na obra de David Harvey. Espaço e Economia, v. 2, n.3, p.1-14, 2013.

CORRÊA, R. L. Espaço, um conceito-chave da geografia. In: CASTRO, I. E.; GOMES, P. C. C.; CORRÊA, R. L. (Orgs.). Geografia: conceitos e temas. Rio de Janeiro: Bertrand Brasil, 1995. p.15-47.

COSTA, J. M. Ação, espaço e território: elementos para pensar uma política de ordenamento territorial. Revista de Políticas Públicas, v.16, n.1, p. 15-24, 2012.

COSTA, J. M.; HIRT, C. Repercussões territoriais das ações públicas e privadas na Amazônia Oriental. Revista Geográfica de América Central, v. 2, p. 1-16, 2011.

COSTA, W.M. Ordenamento territorial e Amazônia: vinte anos de experiências de zoneamento ecológico e econômico. Universidade e Meio Ambiente- Revista do Núcleo de Meio Ambiente da UFPA, v. 1, n. 1, p. 1-28, 2016.

COUTO, M. E. A. Os Ajustes Espaciais: a expansão das redes e a mobilidade informacional no cenário amapaense. In: PORTO, J. L. R. (Org.) Condicionantes construídos: reflexões sobre as transformações espaciais amapaenses. Macapá: S. E., 2007.

CPT - Comissão Pastoral da Terra. Conflitos no Campo Brasil 2018. Goiânia: CPT Nacional, 2019.

CPT - Comissão Pastoral da Terra. Conflitos no Campo Brasil 2019. Goiânia: CPT Nacional, 2020a.

CPT - Comissão Pastoral da Terra (Org.). Atlas de Conflitos Socioterritoriais Pan-Amazônico. Goiânia: CPT Nacional, 2020b.

DURO, J. A. et al. Global inequalities in food consumption, cropland demand and land-useefficiency: A decomposition analysis. Global Environmental Change, v. 64, p. 1-11, 2020.

FEARNSIDE, P. M. Impactos das hidrelétricas na Amazônia e a tomada de decisão. Novos Cadernos NAEA, v. 22, p. 69-96, 2019.

GILBERTONI, C. A. C. A Lei de Modernização dos Portos. Disponível em: <https://ambitojuridico.com.br/cadernos/direito-administrativo/a-lei-de-modernizacao-dos-portos/>. Acessado em: 28 nov. 2019.

GOBBI, G.; CARRARO, I. R.; FURLAN, J. Análise do setor portuário brasileiro: deficiências, transformações e melhorias. Espacios (Caracas), v. 36, n. 5, p. 5-20, 2015.

HAESBAERT, R. Ordenamento Territorial. Boletim Goiano de Geografia, v. 26, p. 117-124, 2006.

HAESBAERT, R. Território(s) numa perspectiva latino-americana. Journal of Latin American Geography, v. 19, p. 141-151, 2020.

HARVEY, D. O problema da globalização. Revista Novos Rumos, v. 28, n. 13, p. 8-16, 1998.

HARVEY, D. El 'nuevo imperialismo: acumulación por desposesión. Socialist Register, n. 42, p. 99-129, 2004.

HARVEY, D. A Produção capitalista do espaço. São Paulo: Annablume, 2005a.

HARVEY, D. O "novo imperialismo": ajustes espaço-temporais e acumulação por desapossamento. Revista Lutas Sociais, v. 13, n.1, p.9-21, 2005b.

HOCSMAN, L. D. Tierra, capital y producción agroalimentaria: despojos y resistencias en Argentina, In: ALMEYRA, G. et al (Orgs.). Capitalismo: tierra y poder en América Latina (1982-2012). Buenos Aires: Continente, 2014.

HUERTAS, D. M. Fluidez territorial em áreas de expansão da fronteira agrícola no período da globalização. GEOUSP, v. 33, p. 60-75, 2013. 
HUYNH, T. L. D.; BURGGRAF, T.; NASIR, M. A. Financialisation of natural resources \& instability caused by risk transfer in commodity markets. Resources Policy, v. 66, p. 1-8, 2020.

LE BRETON, D. L. Ambivalências do risco. Sociologias, v. 21, n. 52, p. 34-48, 2019.

MARGARIT, E. Integração do Amapá ao circuito produtivo da soja. Interespaço: Revista de Geografia e Interdisciplinaridade, v. 4, n. 12, p. 108-119, 2018.

MARGARIT, E. Integração territorial competitiva do Amapá: o programa de aceleração do crescimento e os grandes projetos de desenvolvimento. 2019. 403 f. Tese (Doutorado em Geografia) - Universidade Federal de Goiás, Goiânia, 2019.

MARGARIT, E; MIRANDA, C. P.; BARREIRA, C. C. M. A. A dinâmica territorial das grandes obras de infraestrutura desenvolvidas no Amapá no âmbito do Programa de Aceleração do Crescimento. PRACS: Revista Eletrônica de Humanidades do Curso de Ciências Sociais da UNIFAP, v. 12, p. 1, 2019.

MARTNER-PEYRELONGUE, C. O Porto como nó de articulação entre os âmbitos local e global. Espaço Aberto, v. 5, n. 2, p. 101-122, 2014.

MASSEY, D. Globalización, espacio y poder. In: CEPAL. Memoria del primer Encuentro de Expertos Gubernamentales en Políticas de Desarrollo Territorial en América Latina y el Caribe. Santiago: CEPAL, 2015. p. 9-14.

MONTE-MÓR, R. Urbanização e modernidade na Amazônia contemporânea. In: LIMONAD, E.; HAESBAERT, R.; MOREIRA, R. (Orgs.). Brasil, Século XXI - por uma nova regionalização? Processos, escalas, agentes. Rio de Janeiro: Letra Capital Editora, 2015. p. 112-122.

MTPA - Ministério dos Transportes, Portos e Aviação Civil. Corredores Logísticos Estratégicos: Complexo de Soja e Milho. Brasília: MTPA, 2017.

MOREIRA, R. As categorias espaciais da construção geográfica da sociedade. GEOgraphia (UFF), v. 3, n.5, p. $15-42,2001$.

MOREIRA, R. Uma ciência das práticas e saberes espaciais Revista Tamoios, v. 13, n. 2, p. 26-43, 2017. MOREIRA, J. F.; SANTOS, N. S.; CASTRO, M. E. L. Desenvolvimento, repertório de ação e mobilizações políticas: o conflito na comunidade do Cajueiro. In: In: SANT'ANA JÚNIOR, H. A.; TEISSERENC, M. J. S. A.; BRUSTOLIN, C. (Org.). Desenvolvimento em questão: projetos desenvolvimentistas, resistências e conflitos socioambientais. São Luís: EDUFMA, 2018. p. 155-186.

PAULA, N. M.; SANTOS, V. F.; PEREIRA, W. S. A financeirização das commodities agrícolas e o sistema agroalimentar. Estudos Sociedade e Agricultura, v. 23, n. 2, p. 294-314, 2015.

PEDRO, V. V.; SANT'ANA JÚNIOR, H. A. 'Na lei ou na marra nós vamos ganhar': a judicialização como estratégia de confronto político pela defesa do Cajueiro e seu território. In: SANT'ANA JÚNIOR, H. A.; TEISSERENC, M. J. S. A.; BRUSTOLIN, C. (Org.). Desenvolvimento em questão: projetos desenvolvimentistas, resistências e conflitos socioambientais. São Luís: EDUFMA, 2018. p. 117-153. PLOEG, J. D. Imperios alimentarios, soberanía alimentaria y luchas sociales. Revista Latinoamericana de Estudios Rurales, v. 4, n. 7, p. 165-187, 2018

POLLAK, M. Memória e identidade social. Estudos Históricos, v. 5, n. 10, p. 200-212, 1992.

RAJAO, R.; et al. The rotten apples of Brazil's agribusiness. Science, v. 369, p. 246-248, 2020.

RODRIGUES, J. C. O Arco Norte e as políticas públicas portuárias para o Oeste do estado do Pará (Itaituba e Rurópolis): apresentação, debate e articulações. Revista NERA, v.21, n. 42, p. 202-228, 2018 a.

RODRIGUES, J. C. O Estado a contrapelo: lógica, estratégias e efeitos de complexos portuários no Oeste do Pará. Tese (Doutorado em Desenvolvimento Socioambiental) - Universidade Federal do Pará, Programa de Pós-Graduação em Desenvolvimento Sustável do Trópico Úmido, Belém, 2018b.

RODRIGUES, J. C.; HAZEU, M. T. Projetos de infraestrutura, desastres e indicativos para novos desastres em Barcarena, Pará, Brasil. DRd - Desenvolvimento Regional em debate, v. 9, p. 818-838, 2019.

RODRIGUES, J. C.; LIMA, R. A. P. Grandes projetos de infraestrutura na Amazônia: imaginário, colonialidade e resistências. Revista NERA, v. 23, n. 51, p. 89-116, 2020.

RODRIGUES, J. C.; RODRIGUES, J. C.; CASTRO, E. M. R. Transporte hidroviário, portos e terminais interiores na Amazônia brasileira: uma análise sobre seus papéis na política pública territorial. Revista GEO UERJ, v. 1, n. 25, p. 115-137, 2014.

RODRIGUES, J. C.; RODRIGUES, J. C.; LIMA, R. A. P. Portos do agronegócio e produção territorial da cidade de Itaituba, na Amazônia Paraense. Geosul, v. 34, n. 71, p. 356-381, 2019.

RODRIGUES, J. C.; RODRIGUES, J. C. A produção de complexos portuários no município de Itaituba, Oeste do Pará: lógicas e contradições das políticas públicas. Caminhos de Geografia (UFU), v. 16, n. 56, p. $1-21,2015$

RODRIGUES, J. C.; RODRIGUES, J. C. Política territorial no oeste do estado Pará: identificação, análise e relação da política pública portuária do município de Itaituba. Revista Geográfica Acadêmica, v. 10, p. 27-43, 2016.

RÜCKERT, A. A. A Política Nacional de Ordenamento Territorial, Brasil. Scripta Nova (Barcelona), v. 11, p. 01-20, 2007 
SÁNCHEZ, J-E. Geografia política. Madrid: Editorial Sintesis, 1991.

SANT'ANA JÚNIOR, H. A.; TEISSERENC, M. J. S. A.; BRUSTOLIN, C. (Org.). Desenvolvimento em questão: projetos desenvolvimentistas, resistências e conflitos socioambientais. São Luís: EDUFMA, 2018.

SANTOS, M.; SOUZA, M. A. A.; SILVEIRA, M. L. Prefácio. In: SANTOS, M.; SOUZA, M. A. A.; SILVEIRA, M. L. (Orgs). Território, globalização e fragmentação. São Paulo: Hucitec/ANPUR1, 1998. p. 11-13.

SILVA, A. L. et al. Políticas ambientais seletivas e expansão da fronteira agrícola no Cerrado: impactos sobre as comunidades locais numa Unidade de Conservação no oeste da Bahia. Revista NERA, v. 22, n. 47, p. 321-347, 2019.

SILVA, R. F. B. et al. The Soybean Trap: Challenges and Risks for Brazilian Producers. Front. Sustain. Food Syst. v. 4, n.12, p. 1-13, 2020.

SILVEIRA, M. R. (Org.). Circulação, transportes e logística: diferentes perspectivas. São Paulo: Outras Expressões, 2011

SILVEIRA, M. R. A competitividade territorial: alguns elementos para discussão. Revista Entre-Lugar, V. 11, n.21, p. 45-74, 2020.

SOUZA, M. L. Os conceitos fundamentais da Pesquisa sócio-espacial. Rio de Janeiro: Bertrand Brasil, 2018.

SPADOTTO, B. R.; COGUETO, J. V. Avanço do agronegócio nos cerrados do Piauí: horizontalidades e verticalidades na relação entre o ambientalismo dos pobres e o controle de terras pelo capital financeiro. Revista NERA, v. 22, n. 47, p. 202-229, 2019 ,

STABILE, M.C. et al Solving Brazil's land use puzzle: Increasing production and slowing Amazon deforestation. Land Use Policy, v. 9, p. 1-6, 2020

SVAMPA, M. Las fronteras del neoextractivismo en América Latina: Conflictos socioambientales, giro ecoterritorial y nuevas dependencias. Guadalajara: CALAS, 2019.

WESZ JR, V. J. Strategies and hybrid dynamics of soy transnational companies in the Southern Cone. Journal of Peasant Studies, v. 43, n. 2. p. 1-27, 2016.

YE, J. et al. The incursions of extractivism: moving from dispersed places to global capitalismo. The Journal of Peasant Studies, v. 47, n. 1, p. 155-183, 2020.

ZHOURI, A. Violência, memória e novas gramáticas da resistência: o desastre da Samarco no Rio Doce. Repocs, v.16, n.32, p. 51-68, 2019. 